\title{
Precious metal enrichment at low-redox in terrestrial native Fe-bearing basalts investigated using laser-ablation ICP-MS
}

Geoffrey H. Howarth ${ }^{1,2}$, James M.D. Day ${ }^{3}$, John F. Pernet-Fisher ${ }^{1,4}$, Cyrena A. Goodrich ${ }^{5,6}$, D. Graham Pearson ${ }^{7}$, Yan Luo ${ }^{7}$, Viktor. V. Ryabov ${ }^{8}$, Lawrence A. Taylor ${ }^{1}$

${ }^{1}$ Planetary Geosciences Institute, Earth and Planetary Sciences Dept., The University of Tennessee, Knoxville, TN, 37996 USA

${ }^{2}$ Department of Geological Sciences, University of Cape Town, Rondebosch 7701, South Africa

${ }^{3}$ Geosciences Research Division, Scripps Institution of Oceanography, UCSD, La Jolla, CA 92093-0244, USA

${ }^{4}$ School of Earth, Atmospheric and Environmental Sciences, University of Manchester,

Oxford Road, Manchester, M13 9PL, UK

${ }^{5}$ Planetary Science Institute, 1700 E. Ft. Lowell, Tucson, AZ, 85719 USA

${ }^{6}$ Lunar and Planetary Institute, 3600 Bay Area Blvd. Houston, TX 77058 USA

${ }^{7}$ Department of Earth and Atmospheric Sciences, University of Alberta, Edmonton, Alberta, Canada

${ }^{8}$ V.S. Sobolev Institute of Geology \& Mineralogy, Siberian Branch, Russian Academy of Sciences, Novosibirsk, Russia 


\section{Abstract (402 words)}

Primary native $\mathrm{Fe}$ is a rare crystallizing phase from terrestrial basaltic magmas, requiring highly reducing conditions $\left(\mathrm{fO}_{2}<\right.$ iron-wüstite buffer) in order to form. Reducing conditions in basaltic magmas can be achieved through assimilation of carbonaceous crustal material, which leads to formation of an immiscible, molten, C-rich, native Fe alloy liquid. If this liquid also contains sufficient sulfur, it can undergo further division into conjugate Fe-C-rich and a Fe-S-rich immiscible melts that can effectively scavenge the highly siderophile elements (HSE: Re, $\mathrm{Au}$, and the platinum group elements [PGE], Pd, Pt, Rh, $\mathrm{Ru}, \mathrm{Ir}, \mathrm{Os})$, as well as $\mathrm{Ni}$ and $\mathrm{Cu}$, to economic abundances. Three localities are known globally where native Fe bearing mafic rocks occur: 1) Paleocene basalts of Disko Island, west Greenland; 2) a Miocene lava of the Bühl basalts, Germany; and 3) mafic intrusions associated with the Late Permian Siberian flood basalts. In this contribution, we report major- and minor-element compositions and HSE concentrations for the main alloy phases (FeNi metal and cohenite) and sulfide, for all three known global occurrences of native Fe bearing basalt. Total HSE abundances in metal grains, obtained by laser ablation inductively coupled plasma mass spectrometry (LA-ICP-MS), are lowest in the Bühl basalt, ( 0.05 ppm), intermediate in the Disko Island basalts (4 to $8 \mathrm{ppm}$ ), and highest the Siberian Khungtukun and Dzhaltul intrusions (10 to 30 ppm). These differences demonstrate that, while native Fe formation is the result of carbonaceous crustal assimilation, HSE enrichment is not ubiquitous during this process. The Siberian occurrences are characterized by Pt PGE (PPGE: Pt, Pd) enrichment relative to the Ir PGE (IPGE: Rh, Ru, Ir, Os), consistent with models of early stage fractionation of olivine, chromite and metallic IPGE in staging magma reservoirs, prior to the addition of C-rich crustal materials in the shallow crust. Relative to Noril'sk Ni-Cu-PGE sulfide ores, the Siberian native Fe basalts are enriched in the PPGE relative to the IPGE, but exhibit Ru enrichments. In contrast, Disko Island native Fe rocks do not show significant fractionation of the PPGE from the IPGE, but have positive Re and Ru anomalies and high Os/Ir ratios. To reconcile these observations, we present a general model where some parental melts experienced early-stage crustal assimilation in staging magma reservoirs, prior to reduction by 
carbon-rich materials (e.g., Khungtukun, Dzhaltul), whereas basaltic parental melts to Disko Island and Bühl solely experienced interaction with carbonaceous material, resulting in extensive devolatilization, native Fe segregation, and native Fe formation.

\section{Introduction}

Highly reducing conditions (i.e., $f \mathrm{O}_{2}<$ iron-wüstite (IW) buffer) during the crystallization of basaltic magmas can lead to formation of native $\mathrm{Fe}$, as has been observed in lunar mare basalts (e.g., Longhi et al., 1974; Papike et al., 1991) and in 'basaltic' eucrite meteorites (Duke, 1965). Highlyreducing conditions during terrestrial basalt petrogenesis are rare, however, with typical crystallization conditions with $\mathrm{fO}_{2}$ equivalent to the quartz-fayalite-magnetite (QFM) buffer (e.g., Toplis and Carroll, 1995). For terrestrial basaltic melts to become reduced, below the IW buffer, assimilation of strongly reducing agents must occur. Reducing agents typically include organic matter-rich or carbon-rich rocks, such as coal beds or carbonaceous black shales. It has been demonstrated that even minor amounts of organic-matter assimilation ( $<0.5$ wt. \%) can decrease the $\mathrm{fO}_{2}$ conditions of a parental magma by several log units (lacono-Marziano et al., 2012). However, it is the addition of carbon that results in the segregation of an immiscible, molten, C-rich, native Fe alloy liquid (e.g., Goodrich and Bird, 1985). Carbon acts to reduce the iron in the melt to metallic Fe ${ }^{0}$ and results in formation of a eutectic between $\mathrm{Fe}$ and $\mathrm{Fe}_{3} \mathrm{C}$ at temperatures consistent with the crystallization of basaltic magmas ( $1154{ }^{\circ} \mathrm{C}$; Chipman, 1973).

Experimental studies have shown that at high carbon ( 1.3 wt. \%) and sulfur ( 2 wt. \%) contents, conjugate $\mathrm{C}$-rich (native Fe) and S-rich (sulfide liquid) molten Fe-C liquids segregate from a common parental magma (e.g., Wang et al., 1991; Corgne et al., 2008). Sulfide liquid immiscibility is a well-described process in terrestrial basaltic magmas, leading to the formation of major $\mathrm{Ni}-\mathrm{Cu}$ platinum-group element (PGE) ores associated with intrusive igneous bodies (e.g., Noril'sk-Talnakh 
ore deposits; Naldrett et al., 1992). In contrast, native Fe has infrequently been observed as a product of post-magmatic reduction and serpentinization of ultramafic rocks in layered intrusions, such as the Muskox intrusion, Canada (Chamberlain et al., 1965). However, in these rare cases, the native Fe is fine-grained, not abundant, and associated with alteration products and not with the PGE enrichment process itself (e.g., Day et al., 2008).

Three occurrences of primary, magmatic native Fe alloys in basaltic rocks have been reported on Earth (Taylor et al., 2014), all of which are associated with intraplate magmatism. These include the Bühl basalt, from the Rhine Graben, Germany (e.g., Hornstein, 1907; Medenbach and EI Goresy, 1982); the 63 Ma Disko Island (Greenland) native Fe bearing basalt occurrences, associated with the North Atlantic Igneous Province (e.g., Nordenskjöld, 1872; Bird and Weathers, 1977); and several intrusions of the 250 Ma Siberia flood basalts, including the Khungtukun and Dzhaltul intrusions (e.g., Ryabov and Anoshin, 1999; Ryabov and Lapkovsky, 2010). Previous studies have shown that these native Fe bearing basalts can become strongly enriched in the highly siderophile elements (HSE: Re, Au, Pd, Pt, Rh, Ru, Ir, Os) (e.g., Ryabov and Anoshin, 1999), which include the economically important PGE (Pd, Pt, Rh Ru, Ir, Os). Here we investigate the origin and associated HSE distribution within native Fe alloys in the three known terrestrial occurrences and examine their petrogenetic histories. Specifically, we examine the origin of elevated HSE concentrations in Siberian basalts versus the Disko and Bühl examples, and compare their HSE petrogenesis with that of world-class PGE deposits in the Noril'sk region of Siberia. These interpretations have implications for the emplacement of large volumes of magma associated with feeder systems to flood basalt provinces.

\section{Native Fe alloy occurrences in terrestrial basalts}

\subsection{Bühl basalt, Kessel, Germany}


Native Fe was first reported in the Bühl basalt at Kessel, Germany (Hornstein, 1907), as a 10 cm native Fe-bearing xenolith within a basalt flow associated with the Miocene Central-European Volcanic Province. Subsequently, Ramdohr (1953) reported more finds from a quarry near Kassel. The study of a native Fe xenolith from this locality by Medenbach and El Goresy (1982) is last published work on these rocks, and little is known about the overall distribution of native $\mathrm{Fe}$ in this basaltic province. Extensive quarrying has removed remnants of this classic native Fe bearing basalt locality.

\subsection{Disko Island, Greenland (63 Ma)}

The first reported occurrence of native Fe in terrestrial basalts was at Disko Island (Greenland) by Nordenskjöld (1872). This initial observation was followed-up in the latter part of the $20^{\text {th }}$ century with several studies detailing the Disko Island occurrences (e.g., Bird and Weathers, 1977; Pederson, 1981; Goodrich, 1984; Goodrich and Bird, 1985). The basalts on Disko Island form part of the North Atlantic large igneous province (LIP), which has been active since the Tertiary (Figure 1). At West Greenland, the effects of wide-spread magmatism in this event led to a present preservation of a 1800 m thick sequence of lavas overlying a $1500 \mathrm{~m}$ thick sequence of CretaceousTertiary carbonaceous shales and sandstones (Clarke and Pederson, 1976). The volcanic sequence is comprised dominantly of picritic lavas ( $1000 \mathrm{~m}$ ) and discrete (10-50 m thick), inter-layered, highly contaminated (20-25\% assimilation; high La/Sm) tholeiitic basalts (Keays and Lightfoot, 2007). Sulfide ( $\mathrm{Cu}-\mathrm{Ni}$ ) and native Fe bearing horizons within the lava sequence are contained within the contaminated basaltic flows. Native Fe has also been reported from dikes and intrusive complexes at Disko Island (Fundal, 1975; Goodrich, 1983), although many samples have been collected as boulders weathered out of the basalts along the coastline. The native Fe within dikes and contaminated basalts typically occurs as fine $(<5 \mathrm{~mm})$ disseminations, whereas boulders with massive 'cumulate' textures have been reported with masses of up to 22,700 kg (Goodrich and Bird, 
1985). These boulders represent the accumulation of native Fe grains within shallow intrusions (sills) related to the overlying basalt sequence. Boulders are generally characterized by high proportions of native Fe (>50 vol. \%) and are interpreted to form by settling and accumulation of $\sim \mathrm{mm}$ sized native Fe grains (Goodrich and Bird, 1985). Therefore, both extrusive and intrusive, native Fe bearing basaltic rocks have been reported from Disko Island. These native Fe basalts have been divided into two chemical occurrences: 1 ) high-C (2.9-4.0 wt. \%) Fe metal, characterized by the occurrence of eutectic cohenite; and 2) low-C (1.8-2.0 wt. \%) Fe metal with eutectoid-textured cohenite (Goodrich and Bird, 1985).

\subsection{The Siberian Large Igneous Province ( $250 \mathrm{Ma})$}

The greatest concentrations of native Fe in terrestrial basaltic rocks are known from intrusions associated with the Siberia LIP, first reported in Russian by Ryabov et al. (1985) and Oleinokov et al. (1985), and more recently in English by Ryabov et al. (1999), Ryabov and Lapkovsky (2010), Kamenetsky et al. (2013) and Ryabov et al. (2014). Due to their high metal abundances, these rocks are commonly mistaken for meteorites samples; however, the presence of native Cu clearly distinguishes them from mesosiderite meteorites (Treiman et al., 2002). Two main occurrences are described from the northwestern Siberian platform: 1) the Khungtukun, Khininda, and Maimecha intrusions, located $500 \mathrm{~km}$ east of the Noril'sk ore deposits, and 2) the Dzhaltul complex, located 200 $\mathrm{km}$ south of the Noril'sk ore region (Figure 1). The Noril'sk-Talnakh region of Siberia is host to one of the largest Ni-Cu-Pd deposits in the world. Ores were formed during the extrusion of the Siberian flood basalts, through assimilation of crustal material and subsequent segregation of immiscible sulfide liquids. Due to the high sulfide-silicate melt partition coefficients, sulfide liquids effectively scavenge the $\mathrm{Ni}-\mathrm{Cu}-\mathrm{Pd}$ in magma reservoirs in the upper-crust. The sulfide bodies are generally contained within irregularities in the footwall of the intrusions due to the higher density of sulfide liquids versus silicate liquid. In contrast, the native Fe-bearing mafic rocks are lenticular intrusive 
bodies associated with the extrusion of the large-scale Siberia flood basalts (e.g., Khungtukun intrusion with a total thickness from 90 to 200 m; Ryabov and Lapkovsky, 2010). The Khungtukun intrusive suites are located within a Carboniferous coal-bearing terrigenous sedimentary sequence. The Dzhaltul intrusion is a complex with a thickness $>500 \mathrm{~m}$, and contains both native Fe mineralization and sulfide mineralization in separate lobes of the intrusion (Ryabov and Lapkovsky, 2010). The Dzhaltul complex was emplaced into a Middle Carboniferous to Permian aged coalbearing terrigenous sedimentary sequence (Ryabov and Lapkovsky, 2010). In both Siberian occurrences, native Fe occurs as nodules in distinct horizons within the intrusive bodies. The textures of the native Fe nodules vary substantially from massive to disseminated (see Ryabov and Lapkovsky [2010]) for detailed descriptions of the different textural variations). Rare occurrences of cross-cutting, native Fe bearing dikes are also observed, which are characterized by disseminated $\mathrm{mm}$-sized native Fe grains. Native Fe within the intrusions does not show textural evidence for accumulation at the base of layers, such as observed for the Disko Island intrusions. Rather, native Fe is associated with roof contacts (Khungtukun) or within the upper parts of what have been interpreted at intrusive pulses, within the Dzhaltul complex (Ryabov and Lapkovsky, 2010).

\section{Analytical methods}

\subsection{Electron microprobe analysis}

Minerals in native Fe bearing rocks were analyzed for major- and minor-element compositions, using a CAMECA SX-100 electron microprobe (EMP) at the University of Tennessee. Analyses were performed with wavelength dispersive spectrometers (WDS), using an accelerating voltage of $15 \mathrm{keV}$, a beam current of $20 \mathrm{nA}$, a $1 \mu \mathrm{m}$ diameter beam for silicates, native metals, and carbides, and $10 \mu \mathrm{m}$ for plagioclase and sulfides, all with standard PAP corrections. Counting times were $20 \mathrm{~s}$ for $\mathrm{Si}, \mathrm{Mg}, \mathrm{Fe}, \mathrm{Na}$, and $\mathrm{Al} ; 30 \mathrm{~s}$ for $\mathrm{Ca}, \mathrm{Cr}, \mathrm{K}, \mathrm{S}$, and $\mathrm{Mn}$; and $40 \mathrm{~s}$ for $\mathrm{P}$. Detection limits ( $3 \sigma$ above background) were 0.03 wt. \% for $\mathrm{Al}_{2} \mathrm{O}_{3}, \mathrm{SiO}_{2}, \mathrm{MgO}, \mathrm{K}_{2} \mathrm{O}$, and $\mathrm{CaO} ; 0.04$ wt. \% for $\mathrm{TiO}_{2}, \mathrm{NiO}$, 
$\mathrm{P}_{2} \mathrm{O}_{5}$, and $\mathrm{Na}_{2} \mathrm{O}$; and 0.05 wt. \% for $\mathrm{FeO}$ and $\mathrm{Cr}_{2} \mathrm{O}_{3}$. The instrument was calibrated daily using both natural and synthetic standards. Standards used for metal analyses were: Fe on hematite; Co, C, Cu, and Ni on pure metals; S on sphalerite; and P on apatite.

\subsection{Laser-ablation-inductively coupled plasma-mass spectrometry (LA-ICP-MS)}

Concentration measurements of the PGE, Re, and Au for the native Fe and sulfide minerals were determined at the Arctic Resources Laboratory, the University of Alberta, using a Resonetics Resolution M-50 ArF (193nm) excimer laser ablation system connected, via Nylon tubing, to a sectorfield ICP-MS Thermo Element 2 XR. The mass spectrometer was operated in low mass resolution mode $(M / \Delta M=\sim 300)$. Samples were ablated in a pure He atmosphere using a dual-volume, LaurinTechnic laser cell and transported to the ICP-MS using an Ar carrier gas. Depending on the size and position, metals were ablated using a spot-size ranging from 90 to $289 \mu \mathrm{m}$, at a repetition rate of 13 $\mathrm{Hz}$ with the laser energy at the target (fluence) regulated at $\sim 7 \mathrm{~J} / \mathrm{cm}^{2}$. Ablation typically lasted for $\sim 60$ seconds. Data were acquired for ${ }^{101} \mathrm{Ru},{ }^{103} \mathrm{Rh},{ }^{106} \mathrm{Pd},{ }^{85} \mathrm{Re},{ }^{191} \mathrm{Ir},{ }^{192} \mathrm{Os},{ }^{196} \mathrm{Pt}$, and, ${ }^{197} \mathrm{Au}$ with a dwell time of $10 \mathrm{~ms}$ for each element. Sulfides were ablated using a spot size of $90 \mu \mathrm{m}$ at a repetition rate of $7 \mathrm{~Hz}$ with laser fluence of 1.5 to $2 \mathrm{~J} / \mathrm{cm}^{2}$. The iron meteorite Hoba was used as the calibration standard for the metals, whereas the FeS standard MASS-1 was used as the calibration standard for

sulfide. In both cases, ${ }^{57} \mathrm{Fe}$ was used as an internal standard using the Fe content obtained by EMP for unknowns. The very low $\mathrm{Cu}$ content of iron metal samples and standard together with low $\mathrm{Cu}$ in the analysed sulfides resulted in negligible $\mathrm{Ar}$ - $\mathrm{Cu}$ interference on Rh. Similarly, inter-element fractionation effects during ablation were accounted for by using closely matrix-matched calibration standards. Sulfide standard La Flamme was used as a secondary standard to monitor the reproducibility of the analyses for metals and sulfides over time. Typical \% RSD levels for all elements analyzed are better than $20 \%$ (9\% for Ru, $13 \%$ for Pd, $10 \%$ for Os, $19 \%$ for $\operatorname{Ir}$ and, $17 \%$ for Pt), and accuracy for the standard was within $2 \sigma$ of reported values. Detection limits varied, 
depending on the analytical conditions (primarily spot-size and fluence), from 5 to $10 \mathrm{ppb}$. Data reduction was conducted using the lolite software, where the time-resolved display and segmentpicking for data integration allows signal spikes from inclusions to be identified and avoided during data reduction.

Analyses by LA-ICP-MS for one Khungtukun sample (YHM) were performed at the University of Maryland, College Park. Concentrations of $\mathrm{Cu}, \mathrm{Mo}, \mathrm{Ru}, \mathrm{Rh}, \mathrm{Pt}, \mathrm{W}, \mathrm{Re}, \mathrm{Os}, \mathrm{Ir}, \mathrm{Pd}$, and Au were determined using a New Wave Research UP213 (213 nm) laser-ablation system coupled to a ThermoFinnigan Element 2 ICP-MS. Metal grains were analyzed using individual spots with a $40 \mu \mathrm{m}$ diameter, a laser repetition rate of $7 \mathrm{~Hz}$, and a photon fluence of 2 to $3.9 \mathrm{~J} / \mathrm{cm}^{2}$. Production of ThO/Th was $0.06 \%$ for the analytical session. Ablation analysis took place in a $3 \mathrm{~cm}^{3}$ ablation cell. The cell was flushed with a He-gas flow of $\sim 0.6 \mathrm{~L} / \mathrm{min}$ to enhance production and transport of fine aerosols, and was mixed with an $\mathrm{Ar}$ carrier-gas flow of $~ 0.8 \mathrm{~L} / \mathrm{min}$ before reaching the torch. Each analysis consisted of $\sim 60 \mathrm{~s}$ data collection. Backgrounds on the sample gas were collected for $\sim 20 \mathrm{~s}$ followed by $\sim 40$ s of laser ablation. Washout time between spots was $>120 \mathrm{~s}$. Data were collected in time-resolved mode so effects of inclusions, mineral zoning, and possible penetration of the laser beam to underlying phases could be evaluated. Plots of counts per second versus time were examined for each analysis, and integration intervals for the gas background and the sample analysis were selected using LAM-TRACE software. Each LA-ICP-MS analysis was normalized to values of $\mathrm{Ni}$ measured by electron microprobe analysis. Time-resolved patterns showed that the ablated volumes were homogeneous. Standardization was performed using the iron meteorites Filomena, Coahuila, and Hoba. Replicate LA-ICP-MS analyses of the iron meteorites run as unknowns gave external precisions of better than $\pm 5 \%(2 \sigma)$.

\section{Results}




\subsection{Siberian Native Fe bearing intrusions}

Sample from the Dzhaltul complex comprise four large (6 to $15 \mathrm{~cm}$ in length) native Fe nodules from the main native Fe-bearing horizon and a hand-sample of doleritic dike, cross-cutting the native Fe-bearing horizon (sample OZ-01-3-1) (Figure 2). All samples contain macroscopic (0.5 to $1.0 \mathrm{~cm}$ ) xenoliths of carbonaceous material. The native Fe-bearing zone is located within the upper portion of the lower-most zone of the complex, interpreted to represent the first intrusive pulse (Ryabov and Lapkovsky, 2010). The native Fe is observed as fine-grained globules within dikes and coarse-grained globules within elliptical nodules in the main native Fe zone. The Khungtukun sample is derived from the $12-40 \mathrm{~m}$ thick native Fe bearing zone associated with the roof contact of the intrusion, and is primarily used for comparison with the Dzhaltul samples.

All samples from the Siberian intrusions are relatively fresh, with minor evidence for rusting of the native Fe at the sample margins. The host rocks of the native Fe globules are composed of a basaltic matrix. The host rock textures are variable within individual samples and include regions characterized by the presence of coarse-grained euhedral olivine phenocrysts (Figure 3a), to finegrained regions comprising plagioclase and olivine included in oikocrystic plates of clinopyroxene (Figure 3b). Boundaries between the silicate and metal phases are sharp and no late-stage alteration products are observed, reflecting the primary nature of the native Fe in these samples.

\subsubsection{Petrography and major-element composition of metals}

Native Fe in the Dzhaltul samples occurs as distinct globules, which are dominantly composed of varying proportions of FeNi metal, cohenite $\left(\mathrm{Fe}_{3} \mathrm{C}\right)$, troilite $(\mathrm{FeS})$, and native-Cu (Figure 2 a-d). Globules range from millimeters to centimeters in diameter. Minor phases include: taenite $(\nu-(\mathrm{FeNi}))$, awaruite $\left(\mathrm{Ni}_{2} \mathrm{Fe}\right)$, other native compounds (e.g., $\mathrm{Sn}-\mathrm{Sb}$ alloys; $\left.\mathrm{Au}\right)$, graphite, $\mathrm{Ni}$-arsenides, schreibersite $\left(\mathrm{Fe}_{3} \mathrm{P}\right)$, and numerous trace phases, as described in detail by Ryabov and Lapkovsky 
(2010b). The dominant native Fe metal phase contains variable amounts of $\mathrm{Ni}$ (1.3-2.0 wt. \%) and Co (0.4-0.8 wt. \%) (Figure 4a; Table 1). Differences in mineralogy occur between individual nodules primarily from the abundance of troilite (absent in sample OZ-101). Sulfide phases in the remaining nodule samples typically occur as distinct globules enclosed in native Fe globules (Figure $\mathbf{2 b}$ ). Troilite is the dominant sulfide phase, with minor amounts of pentlandite and chalcopyrite that are found exsolved around the margins of the sulfide globules. Native-Cu is ubiquitous in the Dzhaltul nodule samples, and generally occurs in association with sulfide globules (Figure 2). In the case of the sulfide-free sample OZ-101, native-Cu appears to have exsolved from the native Fe phase (Figure 2). Cohenite is ubiquitous, forming as eutectoid-textured grains at the interface between the native $\mathrm{Fe}$ and silicates (Figure 2), and contains minor amounts of $\mathrm{Ni}(0.3-0.5$ wt. \%) and $\mathrm{Co}$ ( 0.1 wt. \%).

The cross-cutting dike sample from Dzhaltul is distinctly in mineralogy from the ore-horizon nodules. It contains disseminated fine-grained $(<100 \mu \mathrm{m})$ native Fe + cohenite globules; however, sulfide phases and native-Cu are not observed (Figure 2e). The native Fe has lower abundances of $\mathrm{Ni}$ ( 0.2 wt. \%) and Co (<0.1 wt. \%), relative to the nodule samples (Figure 4a).

Khungtukun native Fe samples differ from Dzhaltul samples in that native-Cu is absent and cohenite is less abundant (Figure 2f). Native Fe also contains higher proportions of $\mathrm{Ni}(\sim 2.2 \mathrm{wt} . \%)$ and Co ( $\sim .6$ wt. \%) relative to Dzhaltul samples (Figure 4a). Sulfide phases are present in low proportions ( 0.1 vol. \%) and are dominated by troilite, although rare exsolved chalcopyrite and pentlandite also occur. The absence of native- $\mathrm{Cu}$ in this sample is consistent with high $\mathrm{Cu}$ contents of the native Fe (0.7 wt. \%), relative to Dzhaltul complex samples ( $\mathrm{Cu}<0.1 \mathrm{wt} . \%)$, and implying exsolution of native $\mathrm{Cu}$ from the Dzhaltul occurrences.

\subsubsection{Highly siderophile element abundances of Siberian metals}


The HSE concentrations of the native Fe from the Dzhaltul and Khungtukun intrusions are similar (Figure 4), with total HSE concentrations ranging from 8 to $30 \mathrm{ppm}$ for Dzhaltul, and 7 to $9 \mathrm{ppm}$ for Khungtukun (Table 1). Chondrite-normalized HSE abundances for both the Dzhaltul and Khungtukun samples are plotted in Figure 5. Overall, the patterns indicate significant enrichment in the platinum-PGE (PPGE: Pd, Pt), Re, and Au relative to the iridium-PGE (IPGE: Ru, Ir, Os, [Rh]) (Figure 5). It should be noted that Rh behaves like an IPGE during sulfide fractionation, whereas during basaltic fractionation Rh behaves like a PPGE (e.g., Li et al., 2006). For these reasons, we group Rh with the IPGE, acknowledging that it might also behave as a PPGE. The chondrite-normalized HSE patterns generally show negative Pt anomalies with Pt* (Pt/SQRT $(\mathrm{Pd} \times \mathrm{Ru})$ ) ranging from 0.94 (i.e., nearly flat profiles) to 0.09 (i.e., distinct negative Pt anomalies) (Figure 5). Although Re is enriched relative to the IPGE, the overall patterns show a negative Re anomaly relative to the more compatible PPGE (Figure 5). There is no notable difference in the HSE patterns between the sulfide-bearing (OZ-601; OZ-82; OZ-244) and sulfide-free (OZ-101; OZ-01-3) samples, suggesting that late-stage crystallizing sulfides had little control on the overall HSE budget and, consequently, HSE inter-element fractionations within samples (Figure 5). The Pd/Pt values are generally high, ranging from 3 to 15 , consistent with the Pt negative anomalies. The Re/Os values range from 3 to 7 and Os/Ir ratios are variable $(<1$, up to 5$)$.

Chondrite-normalized HSE patterns for cohenite is OZ-601, OZ-101, and OZ-82 are similar to those of the native Fe patterns described above. The HSE patterns are generally enriched in the PPGE relative to the IPGE, with notable negative Pt anomalies (Figure 5).

Despite the pervasiveness of sulfide phases within most samples, only sulfides in sample OZ-82 from Dzhaltul were coarse enough to determine HSE abundances quantitatively. Sulfides in this sample are dominantly troilite with minor pentlandite and chalcopyrite, and it is likely that the LA- 
ICP-MS analysis sampled heterogeneous proportions of the sulfide assemblages. Total HSE contents of the sulfide globules are variable $(0.4-12.7 \mathrm{ppm})$ between individual grains, but significantly lower than associated native Fe ( $25 \mathrm{ppm})$. The overriding characteristic of the HSE within the sulfide globules is the high Pd/Pt value of 1000 , and distinct Pt negative anomalies, similar to the native $\mathrm{Fe}$ analyses (Figure 5). The metal/sulfide distribution coefficients can be calculated using the concentrations analyzed. Only Pd, Pt, and Ru were in high enough concentrations in the sulfide to analyze. $\mathrm{D}_{\text {metal/sulfide }}$ for $\mathrm{Pd}, \mathrm{Pt}$, and Ru were calculated to be 4, 280, and 9, respectively, highlighting the dominance of Pt in metal over sulfide. The calculated Pt and Pd $\mathrm{D}_{\text {metal/sulfide }}$ are similar to those obtained from experimental studies; Pt 48-300 and Pd 0.8-1.4 (Fleet et al., 1999), whereas the Ru $D_{\text {metal/sulfide }}$ is significantly lower than experimental values of 49-164 (Fleet et al., 1999).

For comparison, we have used the average Noril'sk sulfide HSE concentrations presented by Barnes et al. (2008) as a normalizing factor for native Fe ores, as illustrated in Figure $\mathbf{5 b}$. The native Fe bearing rocks are enriched in the incompatible HSE relative to the sulfide deposits, with an order of magnitude more Re, and are characterized by notable enrichment in Os relative to Noril'sk sulfides. A distinct difference between native Fe ores and the Noril'sk sulfide ores are the positive Ru anomalies $\left(\mathrm{Ru}^{*}=10-20\right)[\mathrm{Ru} * ;(\mathrm{Ru} / \mathrm{SQRT}(\mathrm{Pt} \times \mathrm{Ir}))]$, indicating significant Ru enrichment in the native Fe ores relative to the sulfide ores (Figure 5b).

\subsection{Disko Island Native Fe bearing basalts}

Samples from Disko Island were selected to represent the diverse textural occurrences of native Fe, from massive textures associated with boulders (sample LP Disko), to coarse blebs within basaltic rocks (samples HC 80 and 1872.1482), to fine-grained disseminated native Fe associated with basaltic dikes (sample AS80-2) (Figure 6). Samples of both the low-C (HC-80, LP Disko, and AS80-2), and high-C (1872.1482) native Fe were selected. The Disko Island native Fe is hosted in 
rocks with a fine- to medium-grained basaltic texture, comprising plagioclase and pyroxene. Olivine occurs in two of the samples (LP Disko and 1872.1482). There is no indication of alteration or reaction of the silicate phases with the native Fe, again implying a primary origin for the native Fe in the host rocks.

\subsubsection{Petrography and major-element composition of the Disko metals}

Low-C native Fe samples are characterized by low abundances of cohenite forming as eutectoid-textured grains along the outer margins of native Fe globules. This eutectoid-textured cohenite exsolved sub-solidus from Fe-Ni-C metal during cooling (Figure 6 b-d). Sulfide assemblages are generally observed as distinct blebs enclosed within native Fe globules, texturally indicating the presence of a sulfide-immiscible liquid at the time of formation. The abundance of sulfides is generally low in samples. Sulfides are dominated by troilite, with minor proportions of chalcopyrite and pentlandite exsolved as lamellae or along sulfide-bleb grain boundaries. This sulfide assemblage and texture are typical for immiscible sulfide melts, which solidify to mono-sulfide solid solution, and crystallize to troilite + pentlandite + minor chalcopyrite (Taylor and Liu, 2009). Samples with high native Fe abundance are characterized by silicate melt inclusions within the native Fe (Figure 6c). The $\mathrm{Ni}$ and Co concentrations of the native Fe vary substantially although the $\mathrm{Ni} / \mathrm{Co}$ ratio is constant at $\sim 3.5$ (the exception being AS-80 with Ni/Co of $~ 20$ ). High $\mathrm{Ni}$ and $\mathrm{Co}$ abundances occur in the cumulate sample LP Disko (1.8 and 0.5 wt. \%, respectively), with intermediate concentrations sample HC-80 (1.2 and 0.4 wt. \%, respectively), and low concentrations for the fine-grained globules of sample AS80-2 (0.4 and 0.1 wt. \%, respectively) (Figure 4; Table 1), consistent with prior results (Goodrich and Bird, 1985). Rare schreibersite $\left(\mathrm{Fe}_{3} \mathrm{P}\right)$ was observed in only one sample, AS80-2; here, the native $\mathrm{Fe}$ is also characterized by high-P contents ( $0.4 \mathrm{wt} . \%)$, relative to other samples (see also, Bird and Weathers, 1997). Copper contents are generally low in all samples (0.1-0.2 wt. \%). 
Cohenite is relatively pure with Co contents $<0.3 \mathrm{wt} . \%$ and Ni contents $<0.6 \mathrm{wt} . \%$ (Table 1), consistent with previous analyses of Goodrich and Bird (1985).

The high-C native Fe metals in the Disko Island samples are less common, relative to the lowC varieties, and only one sample was available for study (1872.1482; Figure 6a and b). This sample is characterized by the occurrence of coarse $(\sim 10 \mathrm{~mm})$ native Fe globules, which have a high abundance of eutectic-textured cohenite laths (Figure $6 \mathbf{b}$ ). Sulfide minerals are generally observed in association with cohenite as troilite-pentlandite-chalcopyrite assemblages. Pentlandite has variable concentrations of Co (up to $20 \mathrm{wt}$. \%), a result of the solid solution series with cobaltpentlandite. The native Fe of this sample is characterized by the highest $\mathrm{Ni}$ and Co concentrations (2.5 and 0.7 wt. \%, respectively; Figure 4a; Table 1) for the Disko occurrences, consistent with previous analyses of Goodrich and Bird (1985). Cohenite contains relatively high Co (0.4 wt. \%) and Ni contents (0.8 wt. \%).

\subsubsection{Highly siderophile element composition of the Disko metals}

Total concentrations of the HSE in the native Fe in the Disko Island samples range from 4 to 8 ppm (Figure 4b). Chondrite-normalized HSE patterns are significantly different from those of the native Fe from the Siberian localities, and are characterized by ubiquitous elevated Re abundances, positive Ru anomalies ranging from 4 to 40 , and high Os/Ir values (1 to 10) (Figure 7). Ratios of $\mathrm{Pd} / \mathrm{Pt}$ range from 0.4 to 2 , which are significantly lower than those of the Siberian native Fe alloys. The Re/Os values range from 0.2 to 0.5 , which is a function of relatively high Os, up to $1.2 \mathrm{ppm}$ in sample 1872.1482. In order to make comparisons with the Siberian occurrences, Disko samples were normalized using the average concentration of the four Siberian nodule samples from Dzhaltul (Figure 7). This form of plot reveals relative depletion in the PPGE, the strong positive Re anomaly and significant enrichment in Os in samples 1872.1482 and LP Disko (Figure 7), compared with 
Siberian samples. The two samples with enriched Os also have increased Pt relative to the other Disko Island samples that were analyzed.

Cohenite in Disko samples have $\mathrm{Cl}$-normalized patterns that are broadly similar to those of their associated native Fe grains. The cohenite grains are characterized by ubiquitous Re enrichments relative to the PPGE, distinct Ru positive anomalies, and enrichment in Os (Figure 7).

Sulfide phases occur within most Disko Island samples, but are generally too fine-grained to analyze by LA-ICP-MS. In sample HC-80, however, the sulfide globules were coarse enough to analyze. Sulfide phases in this sample are dominantly troilite, with only minor pentlandite, and chalcopyrite, and have total HSE contents similar to those of the native Fe (1.5 to $2 \mathrm{ppm}$ in the sulfide relative to 1.9 to $2.4 \mathrm{ppm}$ in the native Fe). Similar to the Siberian sulfide globules, the overriding characteristic of the HSE within the sulfide blebs is the high Pd/Pt value of $\sim 1000$, indicating a clear dominance of Pd over Pt in the sulfide assemblages. Calculated $\mathrm{D}_{\text {metal/sulfide }}$ for $\mathrm{Au}$, $\mathrm{Pd}, \mathrm{Pt}$, and $\mathrm{Ru}$ are $8,0.3,120$, and 10 , respectively. In this case, $\mathrm{Pd}$ is more compatible in sulfide than metal.

\subsection{Bühl native Fe bearing basalt}

The two Bühl basalt samples analyzed contain relatively high abundances of native Fe with distinct globular morphologies (Figure 8). The globules are hosted within a fresh fine-grained basaltic textured rock comprising plagioclase and clinopyroxene; no reaction and alteration products were observed between metals and silicates. Individual globules range in size from 20 to $80 \mu \mathrm{m}$ in diameter, and larger aggregates are present where numerous globules coalesce forming elongate globules, indicating some degree of accumulation and compaction. The native Fe within this sample 
is virtually pure Fe (Figure 4a). Troilite was observed along the margins of the native Fe globules (Figure 8), as well as blebs within native Fe globules. No chalcopyrite or pentlandite was observed. The troilite contains no measureable $\mathrm{Ni}, \mathrm{Co}$, or $\mathrm{Cu}$, and is pure Fe-sulfide. Cohenite is a rare constituent forming as similar eutectoid-textures to those observed for low-C varieties from Disko Island. The HSE concentrations of the Bühl basalt samples are low (total HSE of $<0.2 \mathrm{ppm}$ ), with only low concentrations of Pd and Pt being detected $(<0.1 \mathrm{ppm})$ using the LA-ICP-MS technique.

\section{Discussion}

\subsection{Formation of carbon-rich, native Fe alloy immiscible liquids}

Liquid immiscibility can occur in terrestrial magmas as a result of several processes. Immiscible sulfide liquids generally form at a late-stage of magma evolution due to fractional crystallization inducing sulfur saturation (e.g., Naldrett et al., 1992; Li et al., 2005). Sulfur saturation can also be induced by assimilation of feldspathic crustal rocks that forces the basaltic melt composition into an early stage of sulfide liquid immiscibility (e.g., Lightfoot et al., 1993). Alternatively, conjugate immiscible silicate liquids of Fe-P-rich and Si-K-rich compositions form after significant Fe-enrichment in tholeiitic magmas (e.g., Charlier et al., 2011; Kamenetsky et al., 2013; Zhou et al., 2013).

The textures of the native Fe within all three terrestrial occurrences indicate their formation as immiscible C-rich, molten, Fe-alloy liquids (c.f., Goodrich and Bird, 1985; Kamenetsky et al., 2013). The addition of significant carbon, from carbonaceous sediments, reduces the oxygen and sulfur fugacity in the basaltic melt, mainly through volatile loss, such that it forces immiscibility of a Fe-C melt. If a significant proportion of sulfur is present, an additional sulfide immiscible melt may also segregate, as shown experimentally in the Fe-C-S system (e.g., Wang et al., 1991; Corgne et al., 2008). Bleb-shaped sulfides, in association with native-Cu, are observed enclosed within native Fe 
from the Siberian occurrences and Disko Island, indicating the presence of both native Fe liquids and sulfide liquids (Figure $\mathbf{2} \mathbf{b}$ and $\mathbf{5 d}$ ). However, in the case of the Dzhaltul native Fe ore layer, sulfide may be completely absent, suggesting that the occurrence of sulfide immiscible liquids within the ore layer are heterogeneous.

Within the Siberian native Fe bearing basalts, there is therefore evidence for four distinct liquids, in two separate immiscible systems. In the case of silicate melt inclusions within the native Fe conjugate Si-K-rich silicate and Fe-P-rich are observed, indicating silicate liquid immiscibility (Ryabov and Lapkovsky, 2010; Kamenetsky et al., 2013). In addition, sulfide globules within native Fe indicates that the metal Fe-C-S liquid has similarly split to form conjugate Fe-C (native Fe) and Fe-S (sulfide) liquids (this study; Kamenetsky et al., 2013). This occurrence may represent the only terrestrial analog for similar liquids produced experimentally in the Fe-C-S system (e.g., Wang et al., 1991).

The PGE are also defined as HSE, but can also behave as highly chalcophile elements (e.g., Mungall and Brenan, 2014; Barnes \& Ripley, 2016). In particular, Pd and Au are more chalcophile than siderophile (e.g., Fleet and Stone, 1991), and should preferentially partition into sulfide liquid, if the native Fe alloy and sulfide liquids are conjugate. In the sulfide-rich samples from the Dzhaltul complex (e.g., OZ-82), sulfide blebs are generally associated with native- $\mathrm{Cu}$, indicating that the native- $\mathrm{Cu}$ is forming from the sulfide liquid (Figure $\mathbf{2 b}$ ). The native- $\mathrm{Cu}$ associated with the sulfide is characterized by significantly higher $\mathrm{Au}(15-25 \mathrm{ppm})$ and $\mathrm{Ag}$ (20-30 ppm) concentrations relative to the native Fe ( $\sim 1 \mathrm{ppm} \mathrm{Au}$ and $<1 \mathrm{ppm} \mathrm{Ag).} \mathrm{Furthermore,} \mathrm{sulfide} \mathrm{phases} \mathrm{are} \mathrm{characterized} \mathrm{by} \mathrm{high}$ $\mathrm{Pd} / \mathrm{Pt}$ values with $\mathrm{D}_{\text {metal/sulfide }}$ for $\mathrm{Pd}<1$, indicating preferential incorporation of $\mathrm{Pd}$ into sulfide. Sulfide preferentially partitions the more chalcophile elements and, therefore, sulfide liquid and 
native Fe immiscible liquids are likely conjugate, formed in equilibrium where small sulfide globules were trapped within the native Fe.

\subsection{Petrogenetic implications of HSE fractionations in native Fe-bearing basalts}

The HSE can be used to distinguish a variety of processes that are important in understanding the petrogenesis of basaltic rocks, including: sub-aerial volcanic degassing, crustal assimilation, fractional crystallization, interaction with sulfide liquids, and source composition (see Day, 2013 for a review). They are highly compatible in Fe-alloy immiscible liquids relative to silicate liquid, and therefore, partition into the Fe-alloy liquid at the time of its formation (e.g., Fleet et al., 1999). Furthermore, the partition coefficients are significantly greater for FeNi alloys (i.e., native Fe) relative to sulfide phases in the Fe-Ni-S system, with the notable exception of Pd (Fleet et al., 1999; this study). For example, the partition coefficient for Pt in Fe-Ni metal in a Fe-Ni-S liquid is 58-300, whereas for sulfide in the same Fe-Ni-S liquid is 0.2 (Fleet et al., 1999). This is consistent with the significantly lower total HSE concentrations measured in sulfides versus metals in the Siberian samples, and the calculated $D_{\text {metal/sulfide }}$ values. Thus, native Fe will efficiently scavenge the HSE relative to sulfide (and silicates), and so, with the exception of Pd, the HSE ratios and total mass of HSE of the initial basaltic melt parental will be preserved in the native Fe phase. In the following section, we compare and contrast the LA-ICP-MS data presented in this study with the whole-rock data of Pernet-Fisher et al. (2016) from the same samples in order to constrain the HSE fractionations and their implications for the petrogenesis of the native Fe basalts.

\subsubsection{Platinum-PGE (PPGE) fractionations}

The Siberian native Fe is characterized by enrichment of the PPGE versus the IPGE in both whole-rock samples and from LA-ICP-MS analyses of metal phases (Figure 4), implying that this pattern is inherited from the tholeiitic basaltic parent melt. The IPGE are less soluble than the PPGE 
in a silicate melt, indicating that the PPGE enrichment is linked to an early-stage fractionation of olivine, chromite and metallic IPGE phases that preferentially incorporate IPGE over PPGE (e.g., Barnes and Fiorentini, 2008; Song et al., 2009; Mungall and Brenan, 2014). The tholeiitic magmas of the Siberian and Disko Island flood basalt sequences are typically interpreted to result from assimilation-fractionation of picritic magmas within staging chambers in the lower or upper crust (e.g., Lightfoot et al., 1993; Keays and Lightfoot, 2007; Pernet-Fisher et al., 2016). Picritic magmas in flood basalt sequences are generally believed to represent primary magmas unaffected by assimilation-fractionation process, and thus to best represent the mantle source. In general, picritic magmas show relatively flat HSE CI-normalized profiles, without significant fractionation of the PPGE versus the IPGE (Pt/Ir = 2.5 - 5; Ireland et al., 2009; Barnes et al., 2015). Therefore, the PPGE versus IPGE fractionation observed for the Siberian native Fe basalts (whole-rock and LA-ICP-MS Pt/Ir > 100; Pernet-Fisher et al., 2016 and this study respectively) is probably due to fractionation of olivinechromite-metallic IPGE phases in a staging magma reservoir prior to intrusion into the shallow crust. In contrast to Siberian HSE patterns, the Disko Island native Fe does not show enrichment of PPGE versus IPGE (whole-rock and LA-ICP-MS Pt/Ir <15; Pernet-Fisher et al., 2016 and this study respectively) indicating that the Disko native Fe did not experience an earlier stage of silicate fractionation.

Platinum and Pd can fractionate from one another through a variety of processes resulting in variable Pd/Pt values within suites of basaltic rocks. These processes include crystallization of an Ssaturated melt, leaving the silicate melt with significantly lower Pt and Pd concentrations with no significant increase in Pd/Pt (1 to 2), or crystallization of an S-undersaturated melt with the segregation of olivine-chromite-metallic Pt+IPGE phases resulting in increases in $\mathrm{Pd} / \mathrm{Pt}(\mathrm{Pd} / \mathrm{Pt}$ up to 8) at relatively constant Pd concentrations (e.g., Song et al., 2009; Howarth and Prevec, 2013). The native Fe bearing rocks from both Siberia and Disko Island have high Pd/Pt values in both the whole- 
rock (1.2-8.0; Pernet-Fisher et al., 2016) and the LA-ICP-MS data (3-23) (Figure 9), suggesting that the parental magmas were enriched in Pd relative to Pt prior to intrusion at the current level.

\subsubsection{Rhenium, osmium, and ruthenium fractionations}

Some of the HSE may be volatile in volcanic systems; in particular, it has been shown that differences in Re concentrations between subaqueously erupted MORB and subaerially erupted OIB reflects degassing, rather than being characteristic of mantle source (e.g., Sun et al., 2003; Day et al., 2010). This results in a concurrent decrease in Re concentration and Re/Os ratios. Degassing is not responsible for trends in any of the studied native Fe bearing samples. With the exception of sample 1872.1482, this is phenomena is not observed for the native Fe-bearing basaltic rocks, where increased Re/Os is accompanied by decreasing Re and Os concentration (Figure 10).

Sulfide-silicate melt partition coefficients for Re are an order of magnitude less than for Os (Roy-Barman et al., 1998; Lambert et al., 2000; Brenan, 2008). During sulfide fractionation, this results in sulfides rich in Os with low Re/Os values, relative to the residual liquid. However, in the case of native $\mathrm{Fe}$, both Os and Re are highly compatible in the metal phase. The higher Re in the Siberian native Fe metal versus the Noril'sk sulfides (Figure 5b) can be explained by this partitioning behaviour. For Disko Island samples, however, the high Re abundances in the metal grains are significantly greater than for associate sulfide-bearing samples. These anomalies may be the result of assimilation of Re-rich carbonaceous crustal material (e.g., Pašava, 1993). Sediments associated with the metal-bearing basalts at Disko Island have relatively high ${ }^{187} \mathrm{Re} /{ }^{188}$ Os ratios (6-30), consistent with assimilation of Re-rich crustal materials to explain the high and variable ${ }^{187} \mathrm{Re} /{ }^{188} \mathrm{Os}$ ratios (6-37) of some Disko Island samples (Pernet-Fisher et al., 2016). 
Ruthenium shows variable positive anomalies in $\mathrm{Cl}$-chondrite normalized patterns for Disko Island (Figure 7a) and for the Siberian native Fe when normalized to Noril'sk sulfide ore (Figure $\mathbf{5 b}$ ). Generally, Ru, Os, and Ir behave compatibly, partitioning into chromite and metallic IPGE phases relative to silicate, which are typically included in olivine during fractionation of a basaltic magma; they also correlate with $\mathrm{MgO}$ in basaltic sequences (e.g., Brenan et al., 2012). High Ru contents in chromites from komatiitic melts have been linked to the presence of Os-Ir-Ru-rich alloys (e.g., Barnes and Fiorentini, 2008). Because the Ru anomalies observed in the LA-ICP-MS data are not present in the whole-rock data, this likely suggests oversampling of very fine-grained IPGE-rich phases during ablation. Therefore, we suggest that Ru is housed within fine-grained sub-micron alloy phases located within the native Fe.

\subsection{Highly Siderophile element (HSE) enrichment and ore-forming processes}

Concentrations of the HSE in the bulk rocks were estimated using modal abundances of the main phases for those samples where native Fe, cohenite, and sulfide were all analyzed (OZ-82; OZ-601; LP Disko; 1872.1482). These modal abundance reconstructions are compared with the whole-rock data (Pernet-Fisher et al, 2016), and we find generally good agreement. For example, the whole-rock Pt and Pd concentrations measured for the sample OZ-601 are 7.9 and 4.4 ppm, respectively, and effectively represent the concentration of the metal phase. These concentrations are in good agreement with those measured in the same sample via laser ablation in this study with Pt and Pd concentrations of 5.3 and $8.5 \mathrm{ppm}$, respectively (Figure 11b). Similar agreement in noted for Re and Os concentrations for sample OZ-601 (Figure 11a). Therefore, we believe that the HSE concentrations measured via laser ablation in this study are representative of the native Fe in these rocks and can be used to constrain upgrading mechanisms for native Fe occurrences. The Disko Island cumulate sample LP Disko (1-2 ppm) and Siberian native Fe- bearing samples (several ppm to $12 \mathrm{ppm}$ ) have significantly higher HSE abundances than typical concentrations (<0.01 ppm) 
measured in tholeiitic basalts (e.g., Ireland et al., 2009; Day, 2013). In particular, the Siberian native Fe bearing layers are strongly enriched in the HSE, with ore grades (i.e., bulk-rock concentrations) similar to world class PGE ore deposits (e.g., Merensky Reef at 25 ppm [Barnes and Maier, 2002], and Noril'sk sulfide ores at 15 ppm [Barnes et al., 2008]). Modelling Pd and Pt fractionation during olivine-chromite-metallic IPGE phase fractionation with calculated bulk partition coefficients of 0.1 and 6, respectively (e.g., Song et al., 2009), indicates that the high Pd/Pt values observed can be produced in residual liquids through 5-30 \% fractionation of these phases. However, this fractionation cannot account for the significant overall enrichment of the HSE observed (Figure 9).

In Figure 11, we show model R-factor pathways for Re versus Os and Pt versus Pd for LA-ICP-MS data and whole-rock data from Pernet-Fisher et al. (2016). The R-factor, described by Naldrett and Campbell (1979), is typically used in the study of sulfide ore bodies and represents the mass of silicate magma that a segregated sulfide liquid (ore body) has equilibrated with in order to account for its enriched HSE (PGE+Re+Au) concentrations. For example, an R-factor of 100 indicates that for one litre of sulfide liquid there must have been 100 litres of silicate liquid. Details of the R-factor models are given in the Figure $\mathbf{1 1}$ caption, and starting compositions for HSEs are taken from the average tholeiites after Day (2013). Rhenium and Os concentrations of both the Siberian and Disko Island occurrences show high R-factors generally ranging from 100-1000, indicating equilibration of the native Fe metals with large volumes of silicate magma. Whereas the Re and Os show good agreement with the models, the Pt and Pd do not; Pd concentrations are significantly higher than expected for a given Pt concentration. This is likely the result of fractionation of the Pt versus Pd at depth within the staging chamber, implying that parental melts were already relatively enriched in these elements, as noted above.

\subsubsection{Disko Island}


The Disko Island samples represent both lavas and intrusions. For example, sample AS80 represents a lava with low proportions of native Fe metal ( 1-2 vol.\%; i.e., metal:silicate ratio of 1:100), and an R-factor of $\sim 100$. Therefore, the native Fe globules in these samples did not require significant upgrading (increases of HSE) from multiple pulses of magma and simply scavenged the HSE from the basaltic host magma (Figure 13). In contrast, the native Fe cumulate sample LP Disko has high R-factors (approaching 10,000 for Re-Os and 600 for Pt-Pd), consistent with the cumulate native Fe scavenging the HSE from a significant amount of silicate magma and enrichment of Re relative to Pt and Pd during the assimilation of carbonaceous material.

The Disko Island cumulates formed in the feeder systems to overlying flood basalts, and two potential scenarios exist in order to account for their high HSE concentrations. First, native Fe saturation occurred in multiple magmas flowing through the staging reservoir, each of which lost native Fe through gravitational settling, leading to cumulate ore enrichment. In this scenario, the ore body would not be upgraded in HSE as the native Fe would scavenge the HSE from single pulses of magma and settle out, resulting in a large native Fe accumulation, but with HSE concentrations representing the parent magma composition. Alternatively, native Fe saturation was induced in a single magma pulse, with native Fe settling to the base of the magma reservoir. Magma flowing through the system would equilibrate with the native Fe in this scenario, progressively upgrading the ore in the HSE as similarly proposed for upgrading of HSE-rich sulfide ore bodies (e.g., Naldrett et al., 1992; Arndt et al., 2003). We prefer the latter scenario as high R-factors would not be expected from the former. The one anomaly in the Disko Island dataset is that of high-C sample 1872.1482, which has a high R-factor (>10,000 for Re-Os; Figure 11a) but is characterized by coarse-grained $(\sim 1 \mathrm{~cm})$ native Fe globules rather than a cumulate texture. Therefore, these native Fe globules may have initially formed in the feeder system and interacted with multiple pulses of magma flowing through the system prior to being transported to the surface. 


\subsubsection{Siberian native Fe occurrences}

A feature of the Siberian native Fe ores is coarsening upward textures, and the occurrence of native Fe in association with the upper parts of intrusive pulses (Ryabov and Anoshin, 1999; Ryabov and Lapkovsky, 2010). Applying Stoke's law, for a typical basaltic magma (viscosity of $10 \mathrm{~kg} \cdot \mathrm{m} / \mathrm{s}$ and density of $3 \mathrm{~g} / \mathrm{cm}^{3}$ ), a settling velocity for native Fe (density of $7 \mathrm{~g} / \mathrm{cm}^{3}$ and $5 \mathrm{~mm}$ spherical diameter) is calculated to be fast, at $\sim 2 \mathrm{~cm} / \mathrm{s}$. Therefore, on formation of native $\mathrm{Fe}$, the resultant grains should settle rapidly to the base of a magmatic staging chamber. However, this is not the case for the Siberian occurrences, and suggests that either the magma must have been of high-enough viscosity that metal phases could not sink or that the metals formed on a 'mush' layer of silicate (e.g., Marsh, 2006). It is also notable that native Fe liquids form at very-high temperatures ( $1250^{\circ} \mathrm{C}$; Figure 12) (e.g., Goodrich and Bird, 1985), similar to typical basaltic liquidus temperatures. Therefore, whereas saturation and segregation of a native Fe liquid can occur, a small amount of cooling will result in the crystallization of this liquid. This is in contrast to typical sulfide liquids that have significantly lower liquidus temperatures $\left(\sim 900^{\circ} \mathrm{C}\right)$, which are able to stay molten within a cooling magma beyond the solidus temperatures of associated silicates and oxides. This distinction between native Fe and sulfide immiscible liquids is fundamental to understanding the distinct ore-forming processes.

In the conduit-style model for the Siberian sulfide ore, S saturation and the formation of an immiscible sulfide liquid (S-liquid) results from crustal assimilation within upper-crustal chambers (e.g., Naldrett et al., 1992; Lightfoot et al., 1993; Arndt et al., 2003). The sulfide liquid is trapped within irregularities in the footwall of the intrusion, but remains molten. Magmas flowing through the same conduit interact with the sulfide liquid, and due to the highly compatible nature of $\mathrm{HSE}, \mathrm{Ni}$, and $\mathrm{Cu}$ with sulfide liquid, the sulfide liquid effectively scavenges these elements from multiple pulses of magma en route to the surface. This process results in large $\mathrm{R}$-factors associated within 
these ore bodies (e.g., Noril'sk sulfide ore R factor = 1000-10,000; Figure 10). This model, however, does not work for the Siberian native Fe-bearing rocks, because the native Fe liquid has liquidus temperatures to high, precluding a molten native Fe liquid. The Siberian native Fe basalts nevertheless have high R-factors (up to 10,000 for sample OZ-601; Figure 11) requiring that the HSE enrichment of the parental magma occurred prior to intrusion at the current level. The fine-grained native Fe of the dike sample ( $\sim 5$ modal \%; OZ-01-3) analyzed from the Dzhaltul Complex has significantly lower total HSE concentrations ( $\sim 1 \mathrm{ppm})$, relative to those analyzed from the ore layer. However, its Pd concentrations still indicate a high R-factor (>100) suggesting equilibration with a significantly larger amount of silicate liquid than a single parent host melt, supporting some upgrading of the HSE in the parental melt prior to intrusion into the shallow crust.

A model invoking early stage HSE enrichment in lower crustal staging chambers has been proposed for the Noril'sk sulfide ores by Li et al. (2009). This model suggests two stages of sulfide saturation. First, lower crustal assimilation and sulfide immiscible-melt formation occurred in staging chambers (Figure 13). The sulfide liquid becomes progressively upgraded in the HSE, through conduit-style enrichment, scavenging the HSE from multiple pulses of magma flowing through the system, forming an HSE-rich sulfide liquid. Subsequent pulses of magma flowing through the system then re-dissolve the HSE-enriched sulfide, and continue ascent into the upper crust. Second, the HSE-enriched parental magma intruded the upper crust, assimilating country-rock material and inducing a second stage of $\mathrm{S}$ saturation. The upper crustal sulfide ore body is formed through assimilation of upper-crustal material by an HSE-rich parental magma and does not require multiple pulses of magma to upgrade HSE concentrations. In the sulfide-ore model, anhydrite was assimilated (Li et al., 2009), causing re-initiation of immiscible sulfide melt. In the case of the native Fe-bearing samples, carbonaceous material was assimilated, which effectively devolatilized the melt with regards to oxygen and sulfur, thereby producing the native Fe HSE ore body (Figure 13). 


\subsection{Model for native Fe formation}

Our interpretations for the formation of HSE-rich and HSE-poor native Fe bearing basaltic rocks in each of the three occurrences are summarized in Figure 13. Whereas HSE-concentrations in the native Fe are high from Siberia, this is not the case in the Bühl native Fe-bearing basalt. In this case, a basaltic magma has simply assimilated carbonaceous crustal material with resultant devolatilization and separation of a native Fe liquid (Figure 13). The high HSE contents in the native Fe associated with Disko Island are related to successive pulses of magma segregating and fractionating native Fe globules, which progressively concentrates HSE and forms an ore-grade body in the footwall on the feeder conduits to the overlying basalts. In the case of the Siberian basalts, PGE enrichment appears to be more complicated, and is likely related to upgrading mechanisms associated with conduit-style processes, much like models for sulfide ore-forming processes in the Noril'sk region. This process is illustrated in Figure 13, with the potential for the formation of an initial immiscible sulfide melt at depth within a staging chamber, followed by dissolution and upward migration of this ore body within S-undersaturated magmas into shallow crustal chambers. These now HSE (PGE+Re+Au), $\mathrm{Ni}$, and $\mathrm{Cu}$ enriched magmas then assimilate carbonaceous material, undergo devolatilization of oxygen and sulfur.

\section{Summary}

Native Fe is a rare primary component of basaltic magmas, only occurring where magmas have interacted with carbonaceous material in the upper crust. Highly siderophile elements analyzed in situ in mineral phases within the native Fe occurrences from Siberia, Disko Island, and Bühl have allowed constraints to be placed on their formation and ore-forming processes associated with these rocks. The Disko Island cumulate occurrence is consistent with simple fractionation and scavenging of HSE from parental magmas within conduits en route to the surface. Basaltic lavas extruding at the 
surface have been contaminated at depth, with formation of fine-grained native Fe globules as immiscible liquids. These globules scavenge the HSE from the parental magmas and are transported upward and extruded at the surface as native Fe bearing basalts. In the case of the Disko Island occurrence, upgrading of the HSE within staging chambers is not required. Siberian native Fe bearing rocks are characterized by significantly higher HSE concentrations, which cannot be accounted for by simple scavenging from a parent magma, and requires significant upgrading prior to intrusion at the current level. We suggest that a modified model similar to that proposed by Li et al. (2009) may account for this process. Native Fe ores represent a new type of HSE (PGE) ore-grade body, and further exploration in other large igneous provinces where carbonaceous sediments are present in the country rock formations may reveal further examples of these occurrences.

\section{Acknowledgements}

We acknowledge the National Science Foundation (NSF), Division of Earth Sciences for providing funding (EAR-1144337) to LAT and (EAR-1116089) to JMDD. This work was partly supported by the Lunar and Planetary Institute. This is LPI publication \# xxxx. GHH would like to thank post-doctoral research fellowships from the Claude Leon Foundation and the URC postdoctoral funding program through the University of Cape Town for funding in 2015-2017. In addition, we would like to thank Allan Patchen who provided assistance with the EMP. The discussions and suggestions of our Russian colleagues, at the V.S. Sobolev Institute of Geology and Mineralogy in Novosibirsk, are gratefully appreciated. Samples of the Bühl basalts were kindly loaned by Maura Weathers and John Bird. We would like to thanks Chusi Li, Stephen Barnes, and Zoltan Zajacz for detailed reviews, which have helped to improve the manuscript. Rich Walker is thanked for efficient editorial handling and patience through the revision process.

\section{References}

Arndt, N. T., Czamanske, G. K., Walker, R. J., Chauvel, C., \& Fedorenko, V. A. 2003. Geochemistry and origin of the intrusive hosts of the Noril'sk-Talnakh Cu-Ni-PGE sulfide deposits. Economic Geology, 98(3), 495-515.

Barnes, S.-J., Ripley, E.M. 2016. Highly siderophile and strongly chalcophile elements in magmatic ore deposits. In: Harvey, J., Day, J.M.D. (Eds) Highly Siderophile and strongly chalcophile elements in high-temperature geochemistry and Cosmochemistry. Reviews in Mineralogy and Geochemistry, 81, 725-774. 
Barnes, S. J., Mungall, J. E., \& Maier, W. D. (2015). Platinum group elements in mantle melts and mantle samples. Lithos, 232, 395-417.

Barnes, S.-J., Prichard, H. M., Cox, R. A., Fisher, P. C., \& Godel, B. 2008. The location of the chalcophile and siderophile elements in platinum-group element ore deposits (a textural, microbeam and whole rock geochemical study): implications for the formation of the deposits. Chemical Geology, 248(3), 295-317.

Barnes, S.-J., \& Fiorentini, M. L. 2008. Iridium, ruthenium and rhodium in komatiites: evidence for iridium alloy saturation. Chemical Geology, 257(1), 44-58.

Barnes, S.-J., \& Maier, W. D. 2002. Platinum-group element distributions in the Rustenburg layered suite of the Bushveld Complex, South Africa. The geology, geochemistry, mineralogy and mineral beneficiation of platinumgroup elements. Can Inst Min Metal Spec, 54, 431-458.

Bird, J. M., \& Weathers, M. S. 1977. Native iron occurrences of Disko island, Greenland. The Journal of Geology, 359-371.

Brenan, J. M., Finnigan, C. F., McDonough, W. F., \& Homolova, V. 2012. Experimental constraints on the partitioning of $\mathrm{Ru}, \mathrm{Rh}, \mathrm{Ir}, \mathrm{Pt}$ and Pd between chromite and silicate melt: the importance of ferric iron. Chemical Geology, 302, 16-32.

Brenan, J. M. 2008. Re-Os fractionation by sulfide melt-silicate melt partitioning: a new spin. Chemical Geology, 248(3), 140-165.

Chamberlain, J. A., McLeod, C. R., Traill, R. J., \& Lachance, G. R. 1965. Native metals in the Muskox intrusion. Canadian Journal of Earth Sciences, 2(3), 188-215.

Charlier, B., Namur, O., Toplis, M. J., Schiano, P., Cluzel, N., Higgins, M. D., \& Vander Auwera, J. 2011. Largescale silicate liquid immiscibility during differentiation of tholeiitic basalt to granite and the origin of the Daly gap. Geology, 39(10), 907-910.

Chipman, J. 1973. C-Fe (Carbon-Iron), In Metals Handbook, Vol. 8 (8th ed.): Metals Park, Ohio, Am. Soc. for Metals, p. 275-278.

Clarke, D. B., \& Pedersen, A. K. 1976. Tertiary volcanic province of West Greenland. Geology of Greenland, 364, 385.

Corgne, A., Wood, B. J., \& Fei, Y. 2008. C-and S-rich molten alloy immiscibility and core formation of planetesimals. Geochimica et Cosmochimica Acta, 72(9), 2409-2416.

Day, J. M. D. 2013. Hotspot volcanism and highly siderophile elements. Chemical Geology, 341, 50-74. 
Day, J. M. D., Pearson, D. G., \& Hulbert, L. J. 2008. Rhenium-osmium isotope and platinum-group element constraints on the origin and evolution of the 1.27 Ga Muskox layered intrusion. Journal of Petrology, 49(7), 1255-1295.

Day, J. M. D., Pearson, D. G., \& Hulbert, L. J. 2013. Highly siderophile element behaviour during flood basalt genesis and evidence for melts from intrusive chromitite formation in the Mackenzie large igneous province. Lithos, 182, 242-258.

Day, J. M. D., Pearson, D. G., Macpherson, C. G., Lowry, D., \& Carracedo, J. C. 2010. Evidence for distinct proportions of subducted oceanic crust and lithosphere in HIMU-type mantle beneath El Hierro and La Palma, Canary Islands. Geochimica et Cosmochimica Acta, 74(22), 6565-6589.

Duke, M. B. 1965. Metallic iron in basaltic achondrites. Journal of Geophysical Research, 70(6), 1523-1527.

Fleet, M. E., Liu, M., \& Crocket, J. H. 1999. Partitioning of trace amounts of highly siderophile elements in the $\mathrm{Fe}-\mathrm{Ni}-\mathrm{S}$ system and their fractionation in nature. Geochimica et cosmochimica acta, 63(17), 2611-2622.

Fleet, M. E., \& Stone, W. E. 1991. Partitioning of platinum-group elements in the Fe-Ni-S system and their fractionation in nature. Geochimica et Cosmochimica Acta, 55(1), 245-253.

Fundal, E. 1975. The Uivfaq Dike and Related Hybrid Dikes from Southern Disko, West Greenland: Field Relations by Erling Fundal. CA Reitzel.

Godel, B., Barnes, S. J., \& Maier, W. D. 2007. Platinum-group elements in sulphide minerals, platinum-group minerals, and whole-rocks of the Merensky Reef (Bushveld Complex, South Africa): implications for the formation of the reef. Journal of Petrology, 48(8), 1569-1604.

Goodrich, C. A., \& Bird, J. M. 1985. Formation of iron-carbon alloys in basaltic magma at Uivfaq, Disko Island: the role of carbon in mafic magmas. The Journal of Geology, 475-492.

Goodrich, C. A. 1984. Phosphoran pyroxene and olivine in silicate inclusions in natural iron-carbon alloy, Disko Island, Greenland. Geochimica et Cosmochimica Acta, 48(5), 1115-1126.

Goodrich, C. A. 1983. Petrogenesis of native iron-carbon alloys, Disko Island, Greenland. Cornell University, May.

Hornstein, F. F. 1907. Mitteilung fiber das Vorkommen yon makroskopischen Einschliissen gediegenen Eisens in Basalt aus der Gegend von Cassel. Zentralbl Mineral 1907: 276-279

Howarth, G. H., \& Prevec, S. A. (2013). Trace element, PGE, and Sr-Nd isotope geochemistry of the Panzhihua mafic layered intrusion, SW China: Constraints on ore-forming processes and evolution of parent magma at depth in a plumbing-system. Geochimica et Cosmochimica Acta, 120, 459-478. 
lacono-Marziano, G., Gaillard, F., Scaillet, B., Polozov, A.G., Marecal, V., Pirre, M., and Arndt, N.T. (2012) Extremely reducing conditions reached during basaltic intrusion in organic matter-bearing sediments. Earth and Planetary Science Letters, 357-358, 319-326.

Ireland, T. J., Walker, R. J., \& Garcia, M. O. 2009. Highly siderophile element and 187 Os isotope systematics of Hawaiian picrites: implications for parental melt composition and source heterogeneity. Chemical Geology, 260(1), 112-128.

Kamenetsky, V. S., Charlier, B., Zhitova, L., Sharygin, V., Davidson, P., \& Feig, S. 2013. Magma chamber-scale liquid immiscibility in the Siberian Traps represented by melt pools in native iron. Geology, 41(10), 1091-1094.

Keays, R. R., \& Lightfoot, P. C. 2007. Siderophile and chalcophile metal variations in Tertiary picrites and basalts from West Greenland with implications for the sulphide saturation history of continental flood basalt magmas. Mineralium Deposita, 42(4), 319-336.

Lambert, D. D., Frick, L. R., Foster, J. G., Li, C., \& Naldrett, A. J. 2000. Re-Os isotope systematics of the Voisey's Bay Ni-Cu-Co magmatic sulfide system, Labrador, Canada: II. Implications for parental magma chemistry, ore genesis, and metal redistribution. Economic Geology, 95(4), 867-888.

Lambert, D. D., Foster, J. G., Frick, L. R., Li, C. H. U. S. I., \& Naldrett, A. J. 1999. Re-Os isotopic systematics of the Voisey's bay Ni-Cu-Co magmatic ore system, Labrador, Canada. Lithos, 47(1), 69-88.

Li, C., Ripley, E. M., Tao, Y., \& Hu, R. (2016). The significance of PGE variations with Sr-Nd isotopes and lithophile elements in the Emeishan flood basalt province from SW China to northern Vietnam. Lithos, 248, 111.

Li, C., Ripley, E. M., \& Naldrett, A. J. 2009. A new genetic model for the giant Ni-Cu-PGE sulfide deposits associated with the Siberian flood basalts. Economic Geology, 104(2), 291-301.

Li, C., \& Ripley, E. M. 2005. Empirical equations to predict the sulfur content of mafic magmas at sulfide saturation and applications to magmatic sulfide deposits. Mineralium Deposita, 40(2), 218-230.

Lightfoot, P. C., \& Keays, R. R. 2005. Siderophile and chalcophile metal variations in flood basalts from the Siberian trap, Noril'sk region: Implications for the origin of the Ni-Cu-PGE sulfide ores. Economic Geology, 100(3), 439-462.

Lightfoot, P. C., Hawkesworth, C. J., Hergt, J., Naldrett, A. J., Gorbachev, N. S., Fedorenko, V. A., \& Doherty, W. 1993. Remobilisation of the continental lithosphere by a mantle plume: major-, trace-element, and Sr-, Nd-, and $\mathrm{Pb}$-isotope evidence from picritic and tholeiitic lavas of the Noril'sk District, Siberian Trap, Russia. Contributions to Mineralogy and Petrology, 114(2), 171-188.

Longhi, J., Walker, D., Grove, T. L., Stolper, E., \& Hays, J. F. (1974). The petrology of the Apollo 17 mare basalts. In Lunar and Planetary Science Conference Proceedings (Vol. 5, pp. 447-469). 
Mann, U., Frost, D. J., Rubie, D. C., Becker, H., \& Audétat, A. 2012. Partitioning of Ru, Rh, Pd, Re, Ir and Pt between liquid metal and silicate at high pressures and high temperatures-Implications for the origin of highly siderophile element concentrations in the Earth's mantle. Geochimica et Cosmochimica Acta, 84, 593-613.

Marsh, B. D. 2006. Dynamics of magmatic systems. Elements, 2(5), 287-292.

Medenbach, O., \& El Goresy, A. 1982. Ulvöspinel in native iron-bearing assemblages and the origin of these assemblages in basalts from Ovifak, Greenland, and Bühl, Federal Republic of Germany. Contributions to Mineralogy and Petrology, 80(4), 358-366.

Mungall, J. E., \& Brenan, J. M. (2014). Partitioning of platinum-group elements and Au between sulfide liquid and basalt and the origins of mantle-crust fractionation of the chalcophile elements. Geochimica et Cosmochimica Acta, 125, 265-289.

Naldrett, A. J., Asif, M., Krstic, S., \& Li, C. 2000. The composition of mineralization at the Voisey's Bay Ni-Cu sulfide deposit, with special reference to platinum-group elements. Economic Geology, 95(4), 845-865.

Naldrett, A. J., Lightfoot, P. C., Fedorenko, V., Doherty, W., \& Gorbachev, N. S. 1992. Geology and geochemistry of intrusions and flood basalts of the Noril'sk region, USSR, with implications for the origin of the $\mathrm{Ni}-\mathrm{Cu}$ ores. Economic Geology, 87(4), 975-1004.

Nordenskjö1d, A.E. 1872. Account of an Expedition to Greenland in the Year 1870, Part I-V. Geol Mag 1872

Oleinikov, B. V., Okrugin, A. V., Tomshin, M. D., Levashov, V. K., Varganov, A. S., Kopylova, A. G. \& Pankov, Y.U. 1985. Native iron formation in platform basic rocks, Yakutian Scientific Center, Siberian Branch of the Russian Academy of Sciences. Yakutsk (in Russian).

Papike, J., Taylor, L., \& Simon, S. (1991). Lunar minerals. Lunar sourcebook, 121-181.

Pašava, J. 1993. Anoxic sediments-an important environment for PGE; an overview. Ore Geology Reviews, 8(5), 425-445.

Pedersen, A. K. 1981. Armalcolite-bearing Fe-Ti oxide assemblages in graphite-equilibrated salic volcanic rocks with native iron from Disko, central West Greenland. Contributions to Mineralogy and Petrology, 77(4), 307324.

Pernet-Fisher, J. F., Day, J. M. D., Howarth, G. H., Ryabov, V. V., and Taylor, L. A. 2016; in review. Atmospheric outgassing and native-iron formation during carbonaceous sediment-basalt melt interactions. Earth and Planetary Science Letters, in review.

Pernet-Fisher, J. F., Howarth, G. H., Liu, Y., Chen, Y., \& Taylor, L. A. 2014. Estimating the lunar mantle water budget from phosphates: Complications associated with silicate-liquid-immiscibility. Geochimica et Cosmochimica Acta, 144, 326-341. 
Ramdohr, P. 1953. Neue Beobachtungen am Bfihl-Eisen. Sitzungsber dt Akad Wissensch Berlin, K1 Mathem Allg Nat Wiss 1952/7.

Ripley, E. M. 1990. Platinum-group element geochemistry of Cu-Ni mineralization in the basal zone of the Babbitt Deposit, Duluth Complex, Minnesota. Economic Geology, 85(4), 830-841.

Roy-Barman, M., Wasserburg, G. J., Papanastassiou, D. A., \& Chaussidon, M. 1998. Osmium isotopic compositions and $\mathrm{Re}-\mathrm{Os}$ concentrations in sulfide globules from basaltic glasses. Earth and Planetary Science Letters, 154(1), 331-347.

Rutherford, M. J., Hess, P. C., \& Daniel, G. H. 1974. Experimental liquid line of descent and liquid immiscibility for basalt 70017. In Lunar and Planetary Science Conference Proceedings (Vol. 5, pp. 569-583).

Ryabov, V. V., Shevko, A. Y., \& Gora, M. P. 2014. Intrusive Complexes of the Noril'sk Region. In Trap Magmatism and Ore Formation in the Siberian Noril'sk Region (pp. 93-206). Springer Netherlands.

Ryabov, V. V., \& Lapkovsky, A. A. 2010a. Native iron (-platinum) ores from the Siberian Platform trap intrusions. Australian Journal of Earth Sciences, 57(6), 707-736.

Ryabov, V. V., \& Lapkovsky, A. A. 2010b. Unique polymineral association of Co-Ni and noble metal phases in gabbro-dolerite of the Dzhaltul trap intrusion (Siberian Platform). In Doklady Earth Sciences (Vol. 434, No. 2, pp. 1325-1329). MAIK Nauka/Interperiodica.

Ryabov, Y. Y., \& Anoshin, G. N. 1999. Platinum-iron metallization in intrusive traps of the Siberian Platform. Geologiya i geofizika, 40(2), 162-174.

Ryabov, V. V., Pavlov, A. L. \& Lopatin, G. G. 1985. Native iron of the Siberian traps, Nauka Publisher, Novosibirsk (in Russian).

Shearer, C. K., Hess, P. C., Wieczorek, M. A., Pritchard, M. E., Parmentier, E. M., Borg, L. E., ... \& Wiechert, U. 2006. Thermal and magmatic evolution of the Moon. Reviews in Mineralogy and Geochemistry, 60(1), 365518.

Song, X. Y., Keays, R. R., Xiao, L., Qi, H. W., \& Ihlenfeld, C. 2009. Platinum-group element geochemistry of the continental flood basalts in the central Emeisihan Large Igneous Province, SW China. Chemical Geology, 262(3), 246-261.

Sun, W., Bennett, V. C., Eggins, S. M., Kamenetsky, V. S., \& Arculus, R. J. 2003. Enhanced mantle-to-crust rhenium transfer in undegassed arc magmas. Nature, 422(6929), 294-297.

Taylor, L.A., and Liu, Y., 2009, Sulfide inclusions in diamonds: not monosulfide solid solution. Russian Geology and Geophysics 50, 1201-1211. 
Taylor, L.A., Day, J.M.D., Goodrich, C.A., Howarth, G.H., Pernet-Fisher, J.F., Barry, P.H., Ryabov, V., \& Pokhilenko, N.P. 2014. Metallic-Fe deposits in basalts: Siberia, Greenland, and Germany. $21^{\text {st }}$ Annual meeting, The International Mineralogical Association Conf., Johannesburg, SA, Scientific Program, Extended Abstract.

Toplis, M. J., \& Carroll, M. R. 1995. An experimental study of the influence of oxygen fugacity on Fe-Ti oxide stability, phase relations, and mineral-melt equilibria in ferro-basaltic systems. Journal of Petrology, 36(5), 1137-1170.

Treiman, A. H., Lindstrom, D. J., Schwandt, C. S., Franchi, I. A., \& Morgan, M. L. 2002. A "mesosiderite" rock from Northern Siberia, Russia: Not a meteorite. Meteoritics \& Planetary Science, 37(S12), B13-B22.

Wang, C. Y., Zhou, M. F., \& Qi, L. 2007. Permian flood basalts and mafic intrusions in the Jinping (SW China)Song Da (northern Vietnam) district: mantle sources, crustal contamination and sulfide segregation. Chemical Geology, 243(3), 317-343.

Wang, C., Hirama, J., Nagasaka, T., \& Ban-Ya, S. 1991. Phase Equilibria of Liquid Fe-SC Ternary System. ISIJ international, 31(11), 1292-1299.

Yokoyama, T., Walker, D., \& Walker, R. J. 2009. Low osmium solubility in silicate at high pressures and temperatures. Earth and Planetary Science Letters, 279(3), 165-173.

Zhou, M. F., Chen, W. T., Wang, C. Y., Prevec, S. A., Liu, P. P., \& Howarth, G. H. 2013. Two stages of immiscible liquid separation in the formation of Panzhihua-type Fe-Ti-V oxide deposits, SW China. Geoscience Frontiers, 4(5), 481-502.

\section{Figures}

Figure 1. Simplified geological maps showing the distribution of native Fe-bearing basalts in Large Igneous Provinces (LIP) on the (a) Siberian Platform (Khungtukun and Dzhaltul), (b) west Greenland, and (c) Central European Magmatic Province (Bühl). Figure after Pernet-Fisher et al. (2016).

Figure 2. Siberian native Fe bearing basalts. a) Photograph of a typical native Fe nodule from the Dzhaltul complex. Photomicrographs of: b) sulfide-bearing native Fe globule showing the occurrence of native Fe associated with cohenite ( $\mathrm{Coh})$, troilite, and native- $\mathrm{Cu}(\mathrm{Cu})$; c) sulfide-free native Fe bearing sample showing the occurrence of exsolved native- $\mathrm{Cu}(\mathrm{Cu})$ as discrete grains within the native Fe alloy; d) sulfide-bearing native Fe sample from Dzhaltul showing the occurrence of multiple sulfide globules associated with cohenite (Coh); e) native Fe bearing dike sample from the Dzhaltul complex showing the occurrence of native Fe and 
cohenite; f) native Fe basalt from the Khungtukun intrusion showing the occurrence of native Fe with only minor cohenite (sulfide and native-Cu free).

Figure 3. Photomicrographs of silicate and Fe-alloys from the Siberian Dzhaltul Intrusion sample OZ-101. a) Cross-polarized light photomicrograph showing the occurrence of coarse-grained euhedral olivine (OI) and plagioclase (Plag) phenocrysts in a finer-grained basaltic matrix comprising plagioclase and pyroxene. b) Reflected light photomicrograph of the same region as illustrated in (a) showing the relationship between native Fe and silicates. c) Cross-polarized light photomicrograph of a silicate-rich portion. d) Reflected light photomicrograph of the same region as shown in (c).

Figure 4. Nickel, Co, and PGE contents of the dominant native Fe alloy phase in the basalts. a) Microprobe Ni (wt.\%) versus Co (wt.\%); b) LA-ICP-MS total HSE (ppm) versus microprobe Ni (wt.\%).

Figure 5. Siberian native Fe bearing basalts. Chondrite-normalized HSE abundances for the Dzhaltul and Khungtukun samples; plotted from the most incompatible (Re) to the most compatible (Os). Although this is not common practice for many studies of PGE and HSE, it is consistent with typical geochemical convention, as pointed out in Day (2013). a) HSE profiles for average native Fe metal (FeNi metal) analyses for the Dzhaltul and Khungtukun samples; b) HSE profiles normalized to Noril'sk sulfide ores for average native Fe metal (FeNi metal) analyses for the Dzhaltul and Khungtukun samples; c) HSE profiles for average cohenite and sulfide analyses for the Dzhaltul samples. Cl-chondrite after Horan et al. (2003) and Noril'sk sulfide normalizing factor after Barnes et al. (2008). The field for whole-rock analyses is from the same suite of samples and is presented in Pernet-Fisher et al. (2016).

Figure 6. Photomicrographs of the native Fe bearing basalts from Disko Island. a) Native Fe globule from Uivfaq (sample 1872.1482) composed of Fe-alloy, troilite, Cobaltpentlandite (CoPent), and cohenite (Coh); b) Highmagnification image of sample 1872.1482, showing Fe-alloy with eutectic-textured laths of cohenite (Coh); c) native Fe cumulate retrieved as a boulder from the coastline at Uivfaq (sample LP Disko) showing the occurrence of globular silicate (dark material) included within the native Fe; d) High-magnification image of sample LP Disko showing globular troilite and cohenite occurring at the interface between native Fe and silicate minerals; e) native Fe globule from the Hammersdal Complex with inclusions of silicate material and minor troilite; f) fine-grained native Fe globules within a basalt from the Asuk region showing the occurrence of native Fe with troilite, cohenite, and schreibersite $\left(\mathrm{Fe}_{3} \mathrm{P}\right)$. 
Figure 7. Disko Island native Fe basalts. Chondrite-normalized HSE abundances for the Disko Island samples; plotted from the most incompatible (Re) to the most compatible (Os). a) HSE profiles for average native Fe metal (FeNi metal) analyses; b) HSE profiles normalized to the average HSE contents of all data collected for Siberian native Fe ores, allowing direct comparison with the HSE enrichments between the two localities; c) HSE profiles for average cohenite and sulfide analyses. The field for whole-rock analyses is from the same suite of samples and is presented in Pernet-Fisher et al. (2016).

Figure 8. Bühl native Fe bearing basalt. Photomicrographs and BSE images of the native Fe from the Bühl basalt. a) Photomicrograph showing the overall texture of the Bühl native Fe basalts; b) Fine-grained globules of native Fe within a silicate groundmass (see location of image in A); c) High-magnification image of a native Fe globule with associated troilite.

Figure 9. LA-ICP-MS analyses for Pt versus Pd/Pt values for Disko Island and Siberian native Fe basalts. Wholerock (WR) analyses from Pernet-Fisher et al. (2016) are plotted for comparison. Plotted on the figure is the modelled curve for the fractionation of olivine (OI),chromite (Chr) and a metallic IPGE phase with bulk partition coefficients of 6 and 0.1 for Pt and Pd respectively (model conditions after Song et al., 2009 and starting composition of typical tholeiitic basalt after Day, 2013). The model shows that in order to produce the increased Pd/Pt ratios observed for the native Fe bearing basalts, at least 5-30 \% fractionation is required in the presence of minor Pt-alloys. It is clear that while the fractionation can produce the increased Pd/Pt ratio it cannot produce the HSE enrichment observed. The Noril'sk sulfide ore value is an average from Barnes et al. (2008).

Figure 10. Rhenium and Os concentrations with comparisons for the Siberian and Disko Island occurrences.

Figure 11. R-factor models for LA-ICP-MS Re versus Os and Pt versus Pd. Whole-rock (WR) values from PernetFisher et al. (2016) are plotted for comparison; symbols for WR are given in the legend below the figure. The melt starting compositions are taken from the average tholeiite concentration given in Day (2013) with Re 0.38 ppb; Os - 0.64 ppb; Pt - 2.3 ppb; and Pd - 2.2 ppb. a) Re and Os concentrations of the Siberian and Disko Island native Fe basalts plotted with calculated R-factors paths. Path 1: R-factor calculated using a partition coefficients for metal/silicate for $\mathrm{Re}=1.1 \times 10^{5}$ (Mann et al., 2012) and Os $=1.5 \times 10^{4}$ (Yokoyama et al., 2009). Path 2 and 3: R-factor paths calculated for sulfide/silicate using partition coefficients suggested by Lambert et al. (1999); Os is $3.0 \times 10^{4}$ for both paths whereas the partition coefficient for Re is varied from 1000 in path 2 to 10 in path 3. b) LA-ICP-MS Pt and Pd concentrations of the Siberian and Disko Island native Fe basalts plotted with calculated R-factor paths. Path 1: R-factor calculated for sulfide/silicate using partition 
coefficients from Fleet et al. (1999) for $\mathrm{Pt}=10000$ and $\mathrm{Pd}=17000$. Using the newer estimates of sulfide/silicate melts from Mungall and Brenan (2014) in the order of $10^{4}$ to $10^{5}$ does not significantly change the modelled curves. Path 2: R-factor calculated for metal/silicate using partition coefficients from Mann et al. (2012) for Pt $=3.7 \times 10^{4}$ and $\mathrm{Pd}=2.2 \times 10^{3}$.

Figure 12. Iron-carbon phase diagram modified after Chipman (1973) and Goodrich and Bird (1985). This system is shown with the location of the low- $\mathrm{C}$ and high-C liquids shown in terms of their bulk carbon content. Note the high temperature of formation and interception of the liquidus at high temperatures, indicating initial crystallization of these liquids at temperatures $>1200^{\circ} \mathrm{C}$.

Figure 13. Illustration of the formation of native Fe and associated HSE-rich and -poor basaltic rocks at the three known localities on Earth. a) The Bühl basalt does not contain HSE enrichment, forming through the interaction of minimally fractionated (alkali) basaltic magmas with carbonaceous material en route to the surface. Assimilation significantly lowered the $\mathrm{fO}_{2}(<\mathrm{IW})$ resulting in the separation of native Fe immiscible liquid in the form of fine-grained globules that are effectively transported in the magma and erupted as lavas at the surface. b) Disko Island deposit shows variable enrichment in HSE. Basaltic magma extruding at the surface assimilated carbonaceous material at depth, which induced native Fe formation as fine-grained globules. These globules scavenged HSE from the host silicate liquid and were carried to the surface. In contrast, the intrusive native Fe ore bodies require upgrading from multiple pulses of magma flowing through the conduit. c) Siberian native Fe ores require significant HSE upgrading, occurring prior to intrusion into the upper crust. Sulfur saturation in deep-staging chambers is responsible for creating HSE-rich sulfide liquids, which are subsequently dissolved and transported upward by later pulses of magma. These later liquids were then parental to both the Noril'sk style sulfide ores and the native Fe ores, depending on what upper-crustal material was assimilated. Evaporite/anhydrite in the former case and carbonaceous material in the latter. Portions of these models have been modified after Li et al. (2009). 
Table 1. Major element composition of native Fe and cohenite from the Siberian (Dzhaltul, Khungtukun), Disko Island, and Bühl basalts.

\begin{tabular}{|c|c|c|c|c|c|c|c|c|c|c|c|}
\hline Native Fe & $\underline{\mathbf{S i}}$ & $\underline{\mathbf{P}}$ & $\underline{\mathbf{s}}$ & $\underline{\text { Ii }}$ & $\underline{\mathrm{Fe}}$ & $\underline{\text { Co }}$ & $\underline{\mathrm{Ni}}$ & $\underline{\mathrm{Cu}}$ & $\underline{0}$ & $\underline{\underline{C}}$ & Total \\
\hline \multicolumn{12}{|l|}{ Dzhaltul } \\
\hline OZ-601 & - & - & - & - & 97.59 & 0.68 & 1.66 & 0.24 & 0.06 & - & 100.27 \\
\hline OZ-244 & - & - & - & - & 98.77 & 0.46 & 1.32 & 0.09 & 0.12 & - & 100.78 \\
\hline OZ-82 & - & - & - & - & 97.50 & 0.56 & 1.90 & 0.09 & - & - & 100.07 \\
\hline OZ-101 & - & - & - & - & 98.34 & 0.42 & 1.33 & 0.10 & 0.09 & - & 100.31 \\
\hline OZ-01-03 & - & - & - & - & 99.78 & 0.07 & 0.17 & 0.06 & 0.09 & - & 100.20 \\
\hline \multicolumn{12}{|c|}{ Khungtukun } \\
\hline $\mathrm{KH}-5$ & - & - & - & - & 96.38 & 0.58 & 2.17 & 0.65 & 0.08 & - & 99.89 \\
\hline \multicolumn{12}{|l|}{ Disko Island } \\
\hline 1872.1482 & - & 0.11 & - & - & 96.29 & 0.66 & 2.44 & 0.15 & 0.09 & - & 99.78 \\
\hline HC-80 & - & - & - & - & 97.02 & 0.37 & 1.24 & 0.15 & 0.17 & - & 98.99 \\
\hline LP Disko & - & - & - & - & 96.20 & 0.53 & 1.87 & 0.14 & 0.12 & - & 98.88 \\
\hline AS-80 & - & - & - & - & 96.20 & 0.53 & 1.87 & 0.14 & 0.12 & - & 98.88 \\
\hline \multicolumn{12}{|l|}{ Bühl } \\
\hline B943 & - & 0.11 & - & - & 99.62 & - & 0.03 & 0.02 & 0.11 & - & 99.92 \\
\hline B1706 & - & 0.05 & - & - & 97.07 & 0.42 & 1.49 & 0.12 & 0.13 & - & 99.29 \\
\hline \multicolumn{12}{|l|}{ Cohenite } \\
\hline \multicolumn{12}{|l|}{ Dzhaltul } \\
\hline OZ-244 & - & - & - & - & 93.77 & 0.07 & 0.37 & 0.01 & 0.14 & 12.88 & 107.22 \\
\hline OZ-82 & - & - & - & - & 93.35 & 0.11 & 0.54 & 0.01 & - & 13.38 & 107.41 \\
\hline OZ-101 & - & - & - & - & 93.37 & 0.08 & 0.36 & 0.01 & 0.06 & 14.31 & 108.19 \\
\hline \multicolumn{12}{|c|}{ Khungtukun } \\
\hline $\mathrm{KH}-5$ & - & - & - & - & 92.48 & 0.42 & 0.87 & 0.01 & 0.05 & 15.16 & 109.02 \\
\hline \multicolumn{12}{|c|}{ Disko Island } \\
\hline 1872.1482 & - & - & - & - & 92.92 & 0.38 & 0.77 & 0.01 & 0.02 & 13.43 & 107.56 \\
\hline LP Disko & - & - & - & - & 92.44 & 0.33 & 0.60 & 0.01 & 13.16 & 0.11 & 106.68 \\
\hline AS-80 & - & - & - & - & 92.72 & 0.04 & 0.11 & 0.01 & 13.76 & 0.20 & 106.85 \\
\hline
\end{tabular}


Table 2. Highly siderophile element concentrations (ppm) in native Fe, cohenite, and sulfide obtained by LAICP-MS for the Siberian (Dzhaltul, Khungtukun), Disko Island, and Bühl basalts.

\begin{tabular}{|c|c|c|c|c|c|c|c|}
\hline Native Fe & Os & Ir & $\mathbf{R u}$ & $\mathbf{P t}$ & Pd & $\mathrm{Au}$ & $\mathbf{R e}$ \\
\hline \multicolumn{8}{|l|}{ Dzhaltul } \\
\hline OZ-601 & 0.010 & 0.051 & 1.520 & 5.343 & 8.509 & 1.203 & 0.070 \\
\hline OZ-244 & 0.007 & 0.026 & 0.821 & 0.746 & 11.61 & 1.411 & 0.038 \\
\hline OZ-82 & 0.055 & 0.011 & 1.207 & 2.767 & 18.54 & 3.372 & 0.172 \\
\hline OZ-101 & 0.029 & 0.034 & 1.052 & 2.496 & 10.16 & 1.461 & 0.086 \\
\hline OZ-01-3 & - & - & 0.187 & 0.044 & 0.541 & 0.068 & 0.008 \\
\hline \multicolumn{8}{|c|}{ Khungtukun } \\
\hline $\mathrm{KH}-5$ & 0.038 & 0.054 & 0.217 & 1.311 & 6.510 & 0.319 & 0.175 \\
\hline \multicolumn{8}{|l|}{ Disko Island } \\
\hline 1872.1482 & 1.231 & 0.129 & 1.533 & 1.276 & 0.483 & 0.198 & 0.419 \\
\hline HC-80 & 0.015 & 0.009 & 1.389 & 0.118 & 0.362 & 0.077 & 0.072 \\
\hline LP Disko & 0.216 & 0.129 & 1.844 & 1.217 & 0.414 & 0.132 & 0.391 \\
\hline AS-80 & 0.011 & 0.007 & 0.232 & 0.068 & 0.217 & 0.029 & 0.051 \\
\hline \multicolumn{8}{|l|}{ Bühl } \\
\hline B943 & - & - & 0.192 & 0.017 & 0.064 & 0.010 & - \\
\hline \multicolumn{8}{|l|}{ Cohenite } \\
\hline \multicolumn{8}{|l|}{ Dzhaltul } \\
\hline OZ-601 & 0.003 & 0.023 & 0.795 & 2.931 & 4.062 & 0.829 & 0.049 \\
\hline OZ-101 & 0.002 & - & 0.348 & 0.177 & 9.935 & 2.165 & 0.032 \\
\hline OZ-82 & 0.010 & 0.001 & 0.344 & 0.598 & 5.660 & 1.290 & 0.059 \\
\hline \multicolumn{8}{|l|}{ Disko Island } \\
\hline 1872.1482 & 1.013 & 0.002 & 0.806 & 0.039 & 0.034 & 0.013 & 0.120 \\
\hline LP Disko & 0.118 & 0.068 & 1.283 & 0.549 & 0.178 & 0.059 & 0.308 \\
\hline \multicolumn{8}{|l|}{ Sulfide } \\
\hline OZ-82 & - & - & 0.092 & 0.003 & 3.326 & - & - \\
\hline $\mathrm{HC}-80$ & - & - & 0.142 & 0.001 & 1.138 & 0.01 & - \\
\hline
\end{tabular}



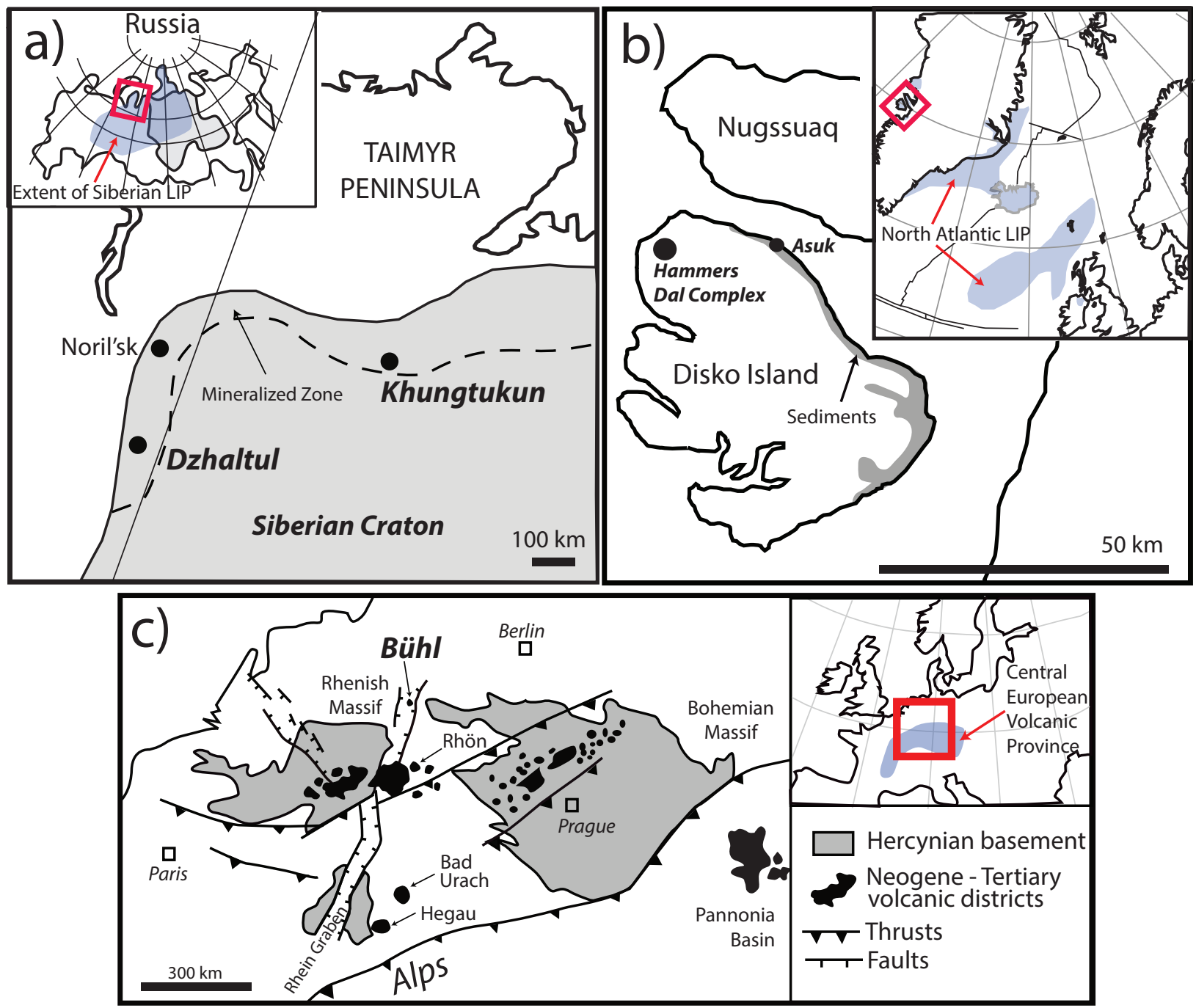

\section{Figure 1}



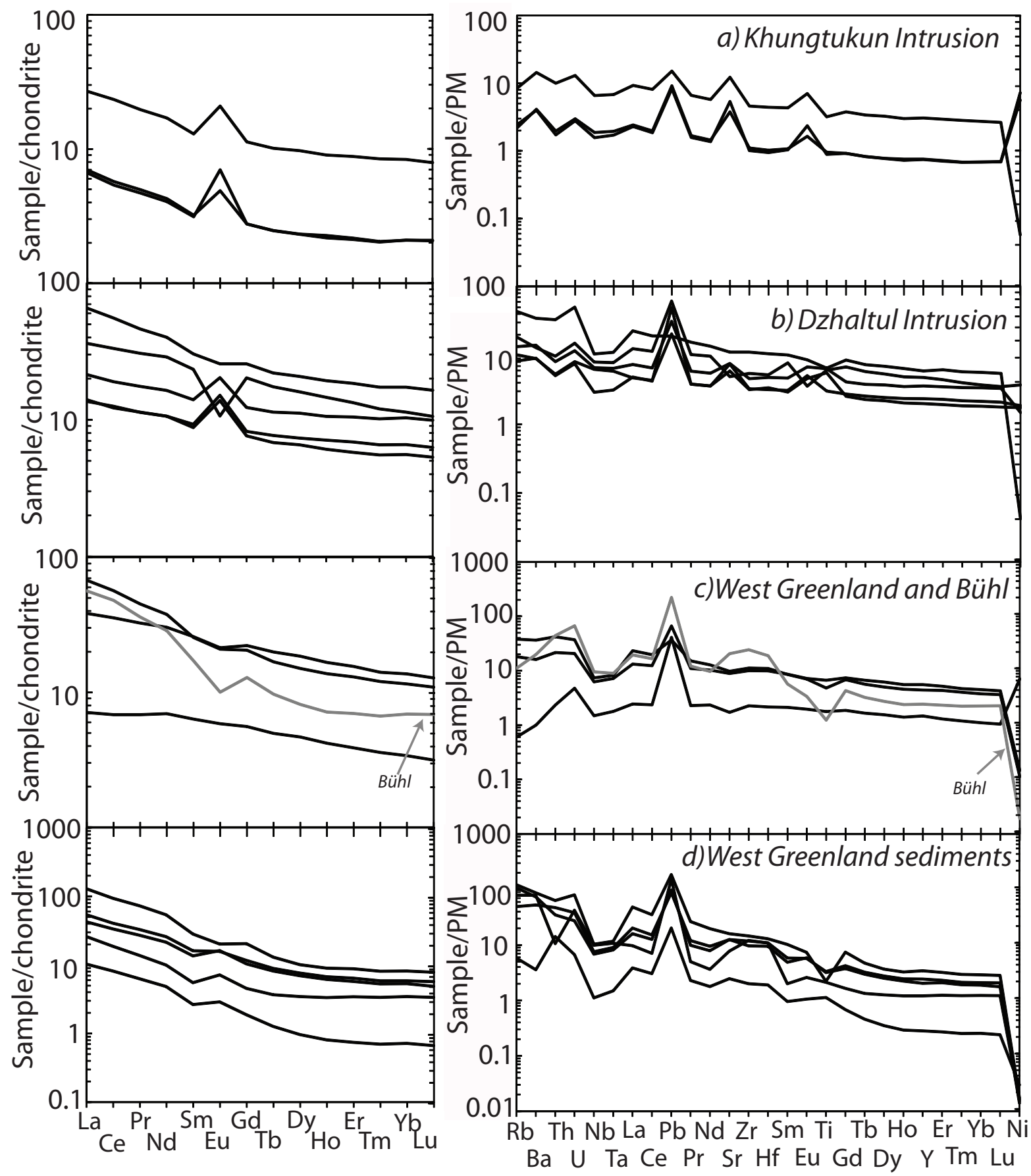

Figure 2 
Figure 3
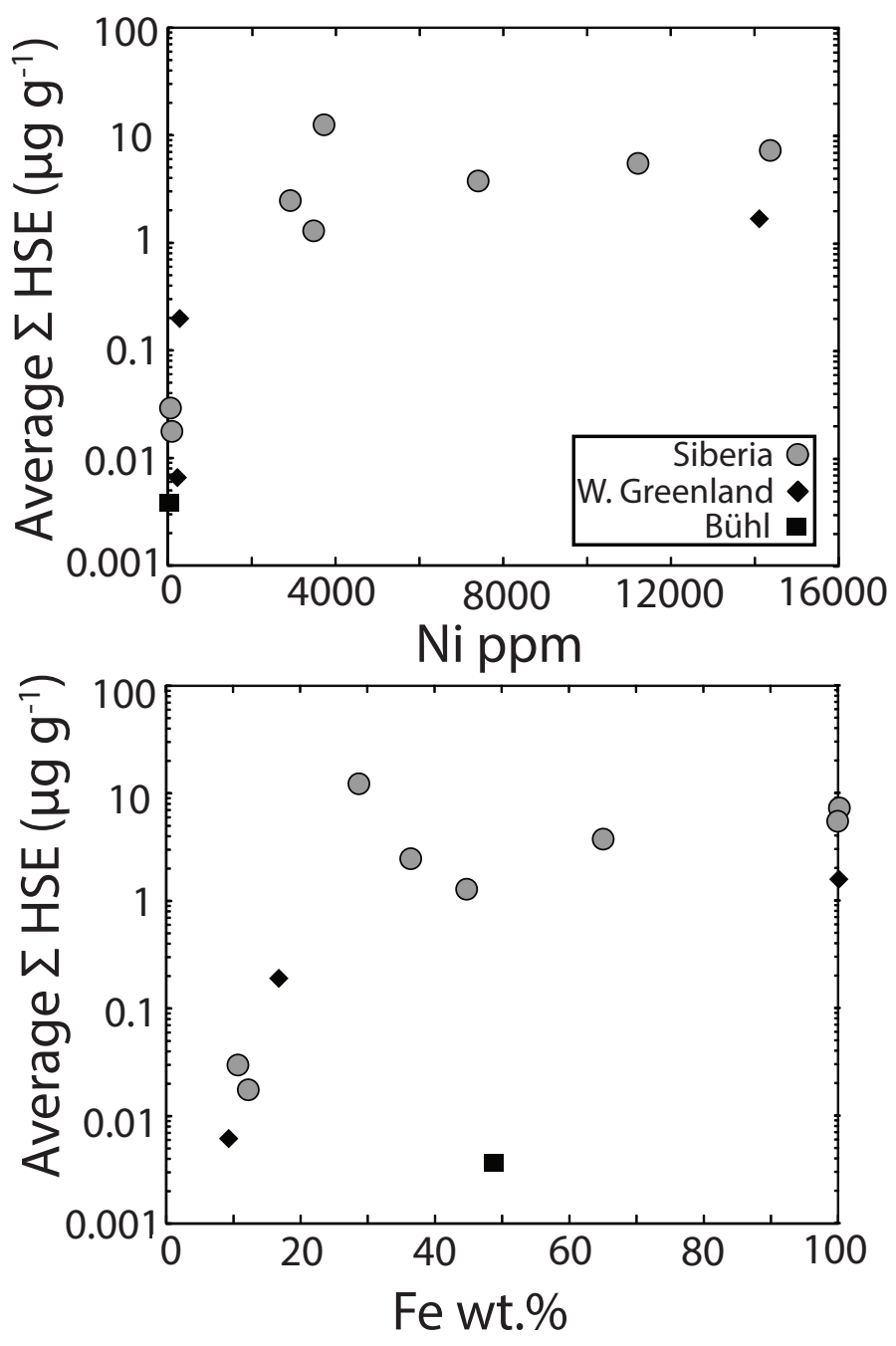

Fig. 3 
a)

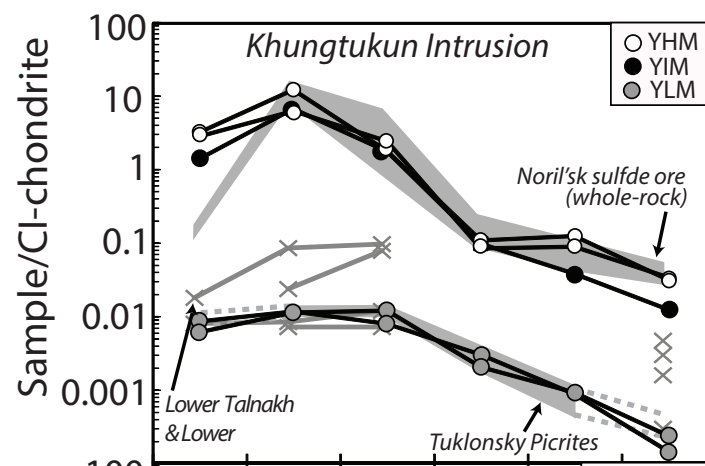

b)

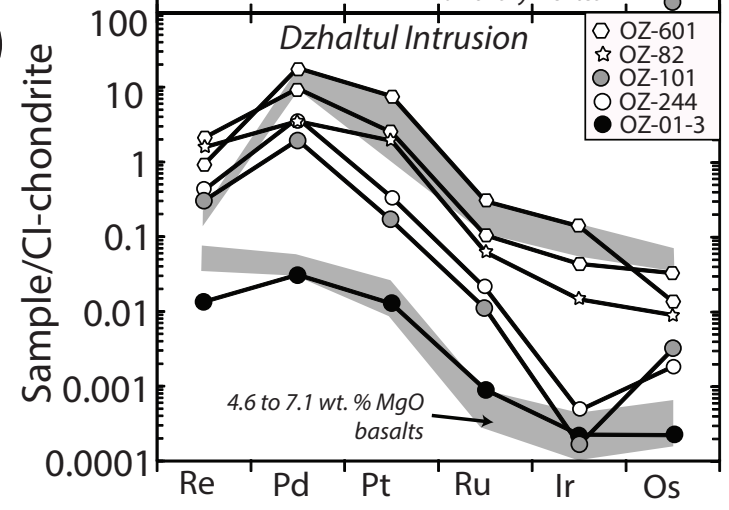

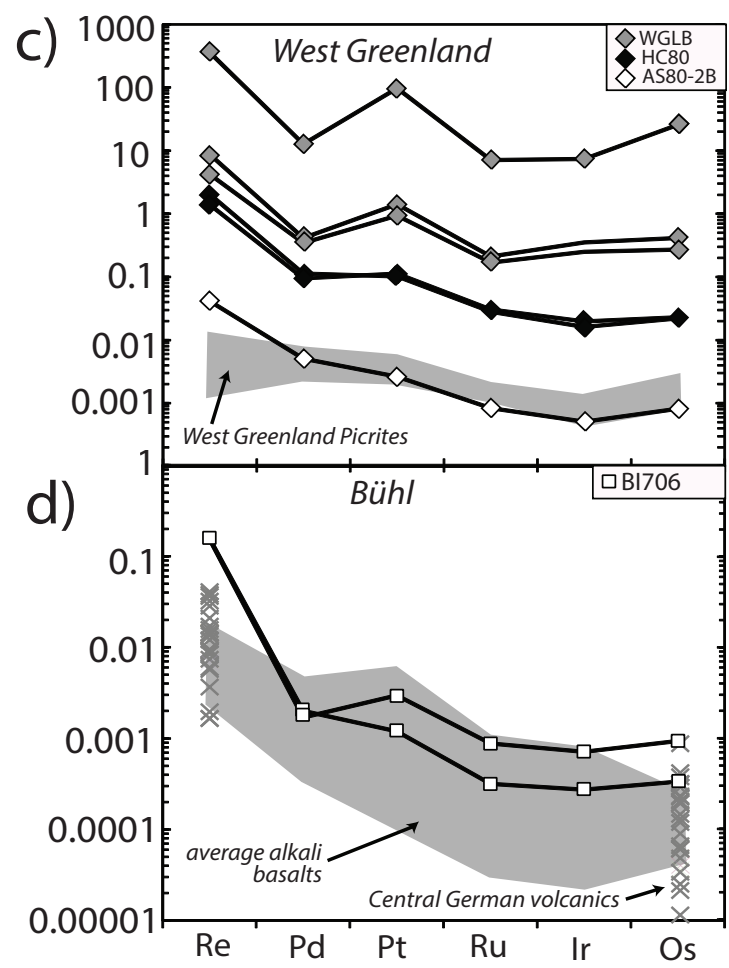

Figure 4 
Figure 5

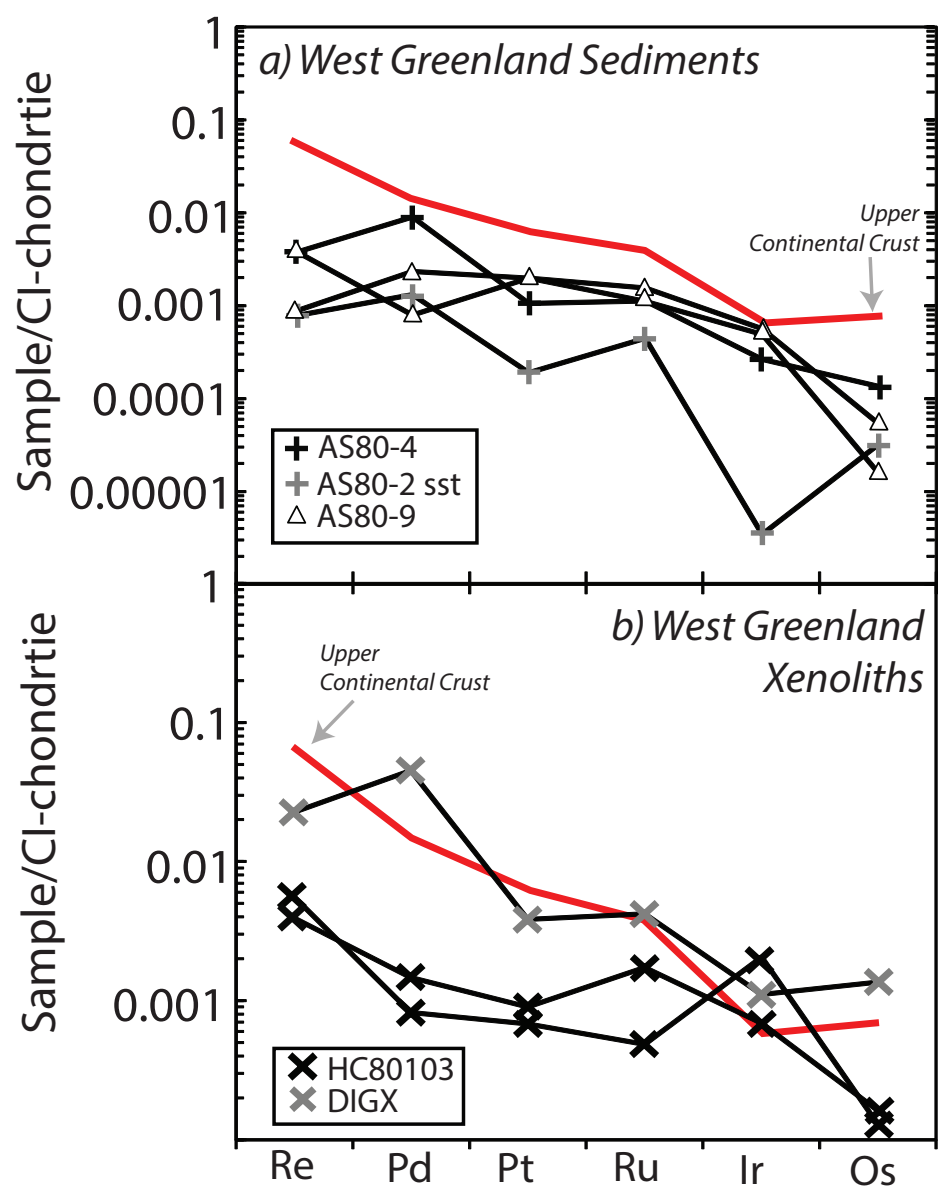

Figure 5 


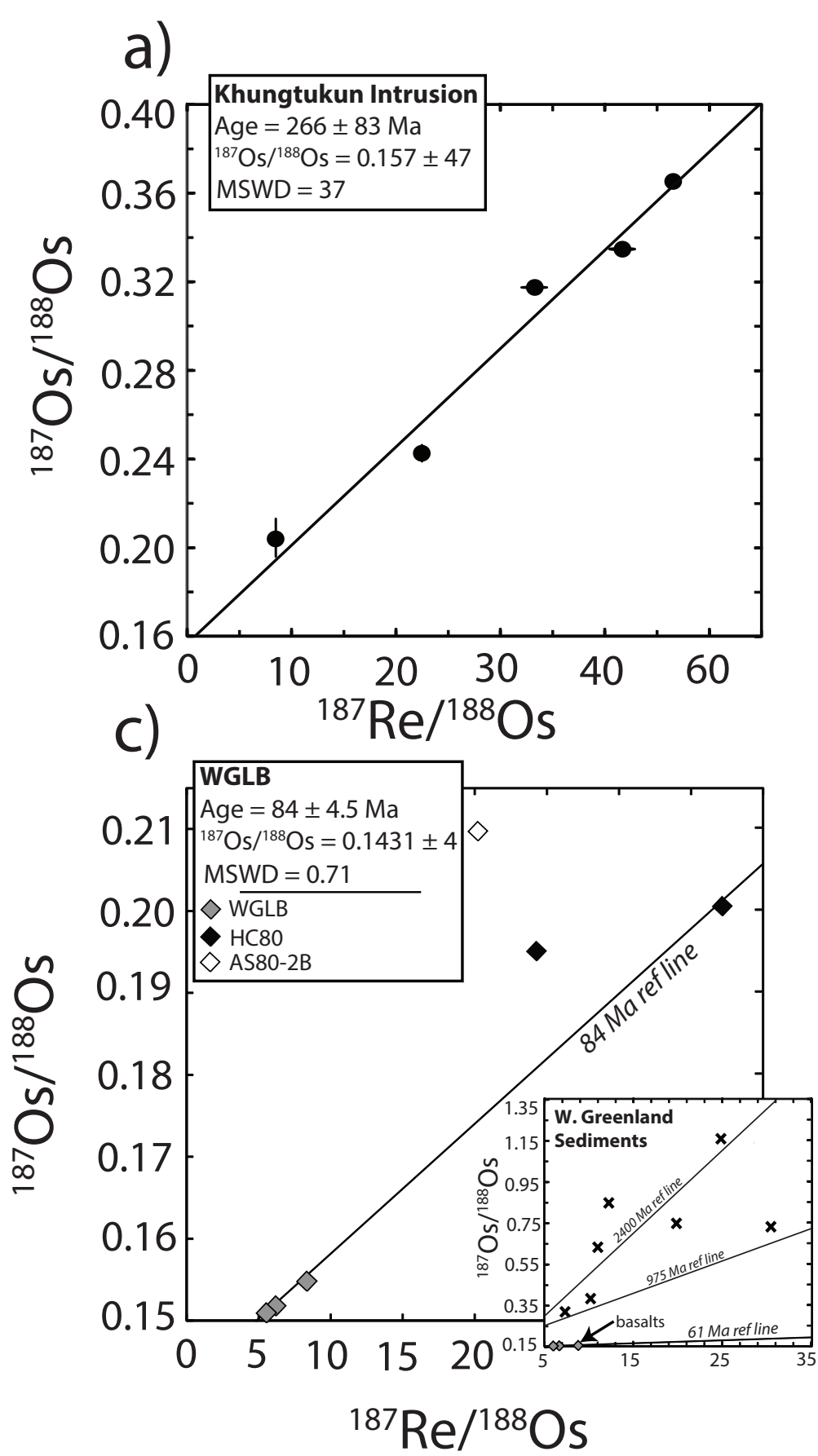

b)
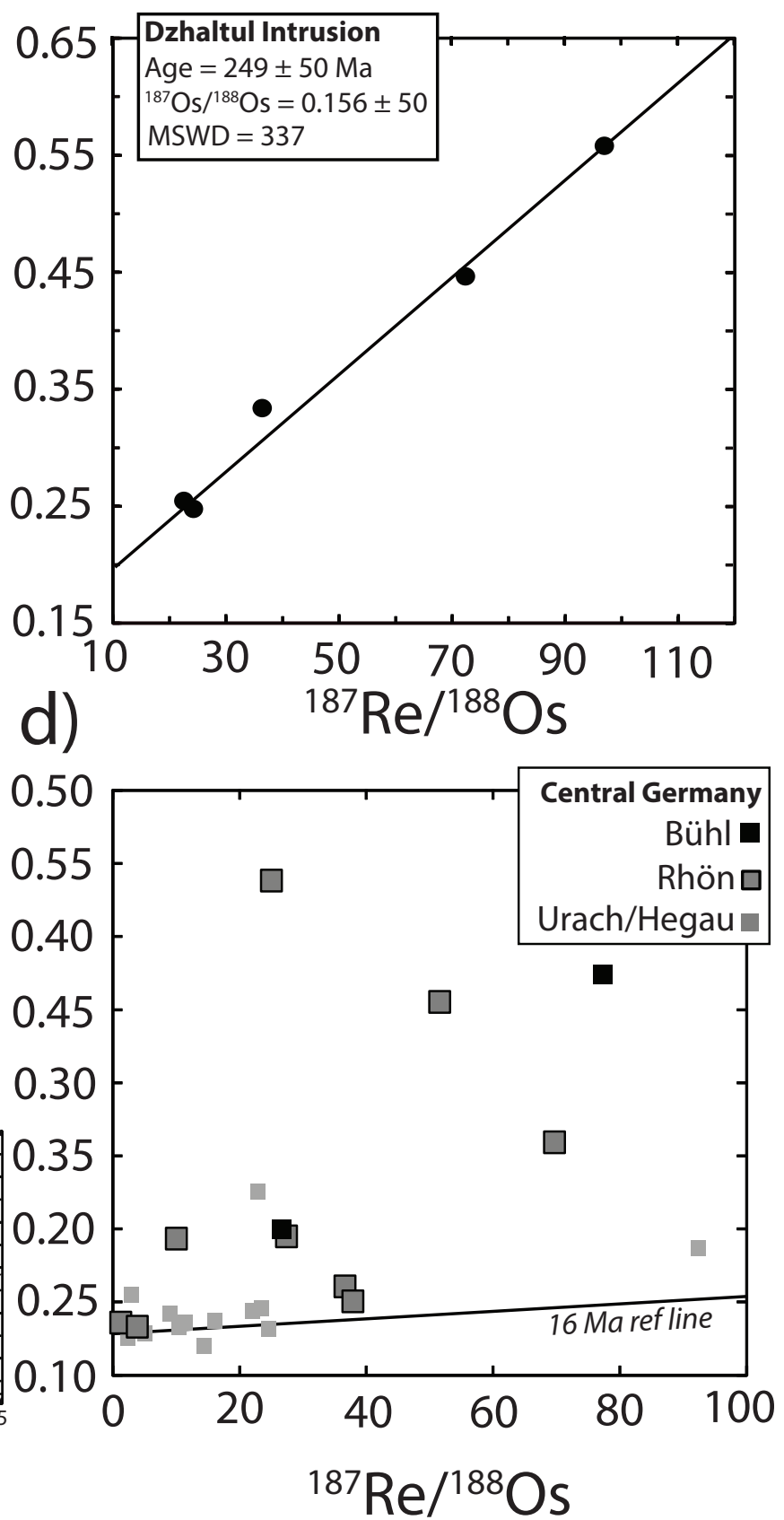

Figure 6 
Figure 7

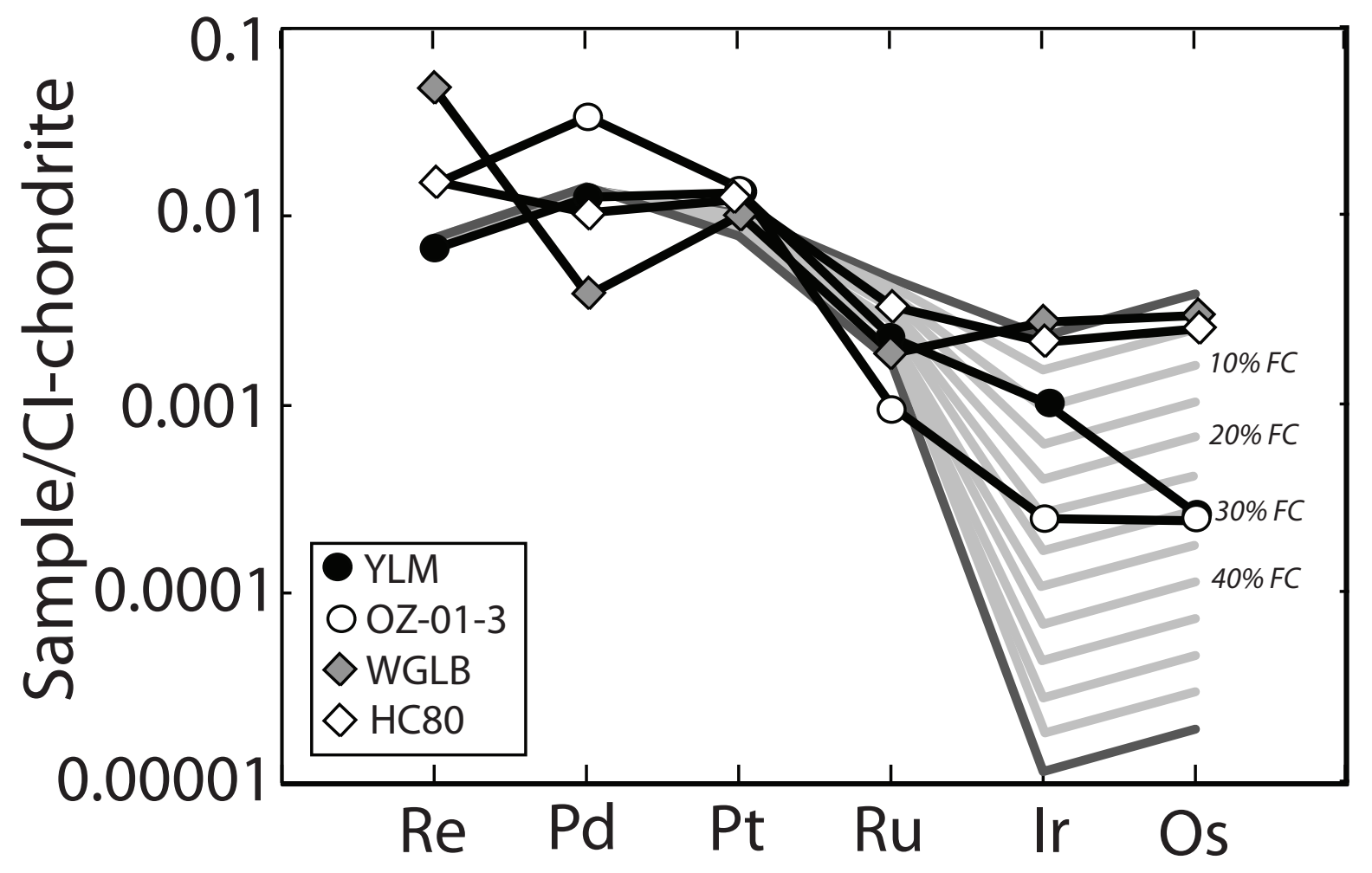

Figure 7 


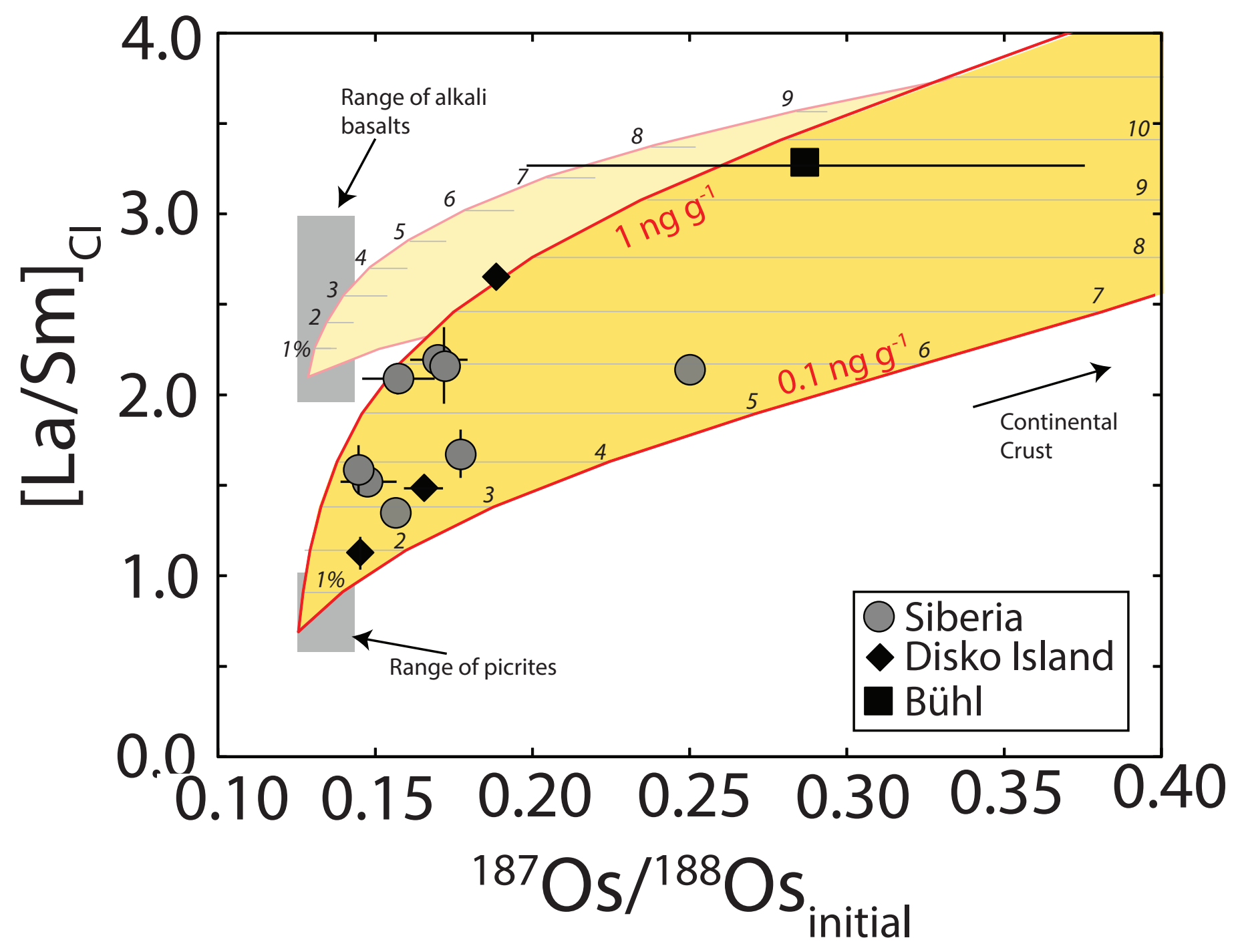

Figure 8 


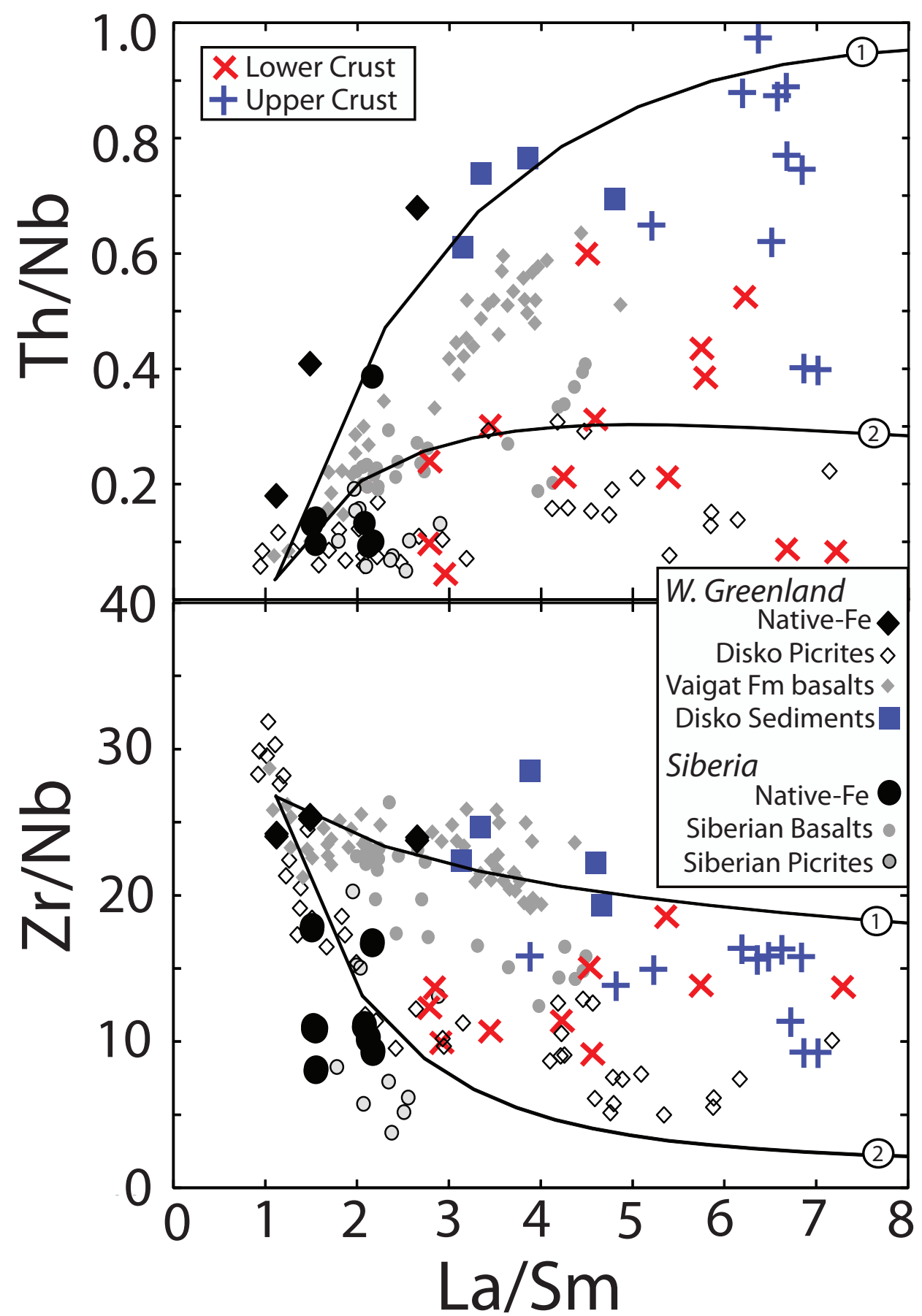

\section{Figure 9}

